\title{
PRÍSPEVOK K OSÍDLENIU SMIŽIAN VO VČASNOSTREDOVEKOM OBDOBÍ⿴囗十
}

\author{
Peter Fecko - Marián Soják
}

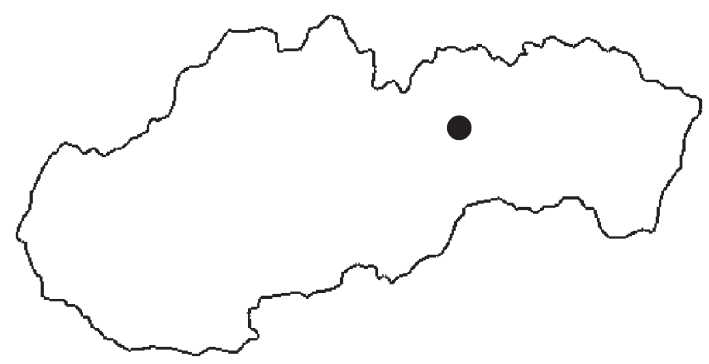

DOI: https://doi.org/10.31577/szausav.2019.66.6

Keywords: Spiš region, Early Medieval period, settlement analysis, reinterpretation of the archaeological findings, settlement, dwelling, ceramics

A contribution to the settlement of Smižany in the Early Middle Ages

The paper offers information about the results of the archaeological research which was accomplished during the construction of the hypermarket TESCO in the village Smižany (district Spišská Nová Ves). The excavated feature can by most probably interpreted as a sunken-floor house. Based on similar analogies from the archaeological sites in the Spiš region and other regions of Slovakia, the excavated findings and the feature itself can be dated to the $8^{\text {th }}$ to $9^{\text {th }}$ century. Archaeological findings from the aforementioned period discovered in the cadastre of Smižany are not rare and are known from the settlements and to a lesser extent from burial grounds. All Early Medieval settlements probably belonged under the administration of the central Čingov hillfort situated in the Slovak Paradise. The analysis of ceramics deposited at the Institute of Archaeology of the SAS - Research department in Spišská Nová Ves pointed out the necessity to revise the ceramic findings from the Spiš region dated to the Early Medieval period and also the necessity to publish all archaeological findings that came from closed finding features.

\section{ÚVOD}

Cielom štúdie je prezentácia výsledkov zo sondážneho archeologického výskumu, ktorý sa realizoval v roku 2011 pri stavbe Obchodného centra TESCO v obci Smižany (okr. Spišská Nová Ves). Počas výskumu sa zistil sídliskový objekt, ktorý na základe analýzy keramického materiálu rámcovo datujeme do 8. -9. stor. Z pohladu chronológie včasného stredoveku na Spiši ide o dôležitý nález, kedž̌e z regiónu poznáme doteraz len málo uzavretých nálezových celkov z daného chronologického horizontu. Väčšinou ide o nálezy zberového charakteru. Lokalita je obzvlášt významná aj kvôli tomu, že sa nachádza v bezprostrednej blízkosti (2,7 km, 30 až 35 minút peši) slovanského hradiska (Hradisko I) situovaného na rozhraní katastrov Spišských Tomášoviec a Smižian.

Obec Smižany patrí do regiónu dolného Spiša, ktorý leží vo Vnútorných západných Karpatoch v nadmorskej výške 450-1122 m (obr. 1; 2: 2). Na východe susedí s okresným mestom Spišská Nová Ves. Na severe hraničí s obcou Iliašovce a na západe s obcami Arnutovce, Spišský Štvrtok, Spišské Tomášovce, Letanovce a Stratená. Na juhu zas s obcami Dedinky a Mlynky (obr. 1). Katastrálne územie má nepravidelný obdížnikovitý tvar s orientáciou od severovýchodu k juhozápadu. Samotné územie môžeme rozdelit na dve časti (obr. 1; 2: 2). Prvú reprezentuje extravilán obce, ktorý tvoria lúky a pasienky. Nachádza sa v severnej časti, patriacej do Fatransko-tatranskej oblasti, ktorej geomorfologickou podkategóriou je už Hornádska kotlina. Južná, rozlohou podstatne väčšia čast' chotára, je zalesnená a patrí do Slovenského rudohoria a v rámci geomorfologickej podkategórie do celku Slovenský raj (Atlas 2001, 88, mapa 21). Územím preteká rieka Hornád s pravostrannými prítokmi Lesnica a Biely potok. Lavostranný prítok predstavuje potok Brusník. V lesnatej časti sú dominantnými kopcami Matka Božia (906 m n. m.), Medvedia hlava (905 m n. m.), Dubnica (990 m n. m.), Zadný Turník (933 m n. m.), Holý kameň (1107 m n. m.) a Suchý vrch (1122 m n. m.). Jednotvárny povrch severovýchodných častí chotára v kotline tvoria ílovce a zlepence tretohorného flyšu, juhozápadne v rudohorí komplexy druhohorných vápencov (Turistický atlas, list číslo

1 Práca vznikla v rámci grantového projektu agentúry VEGA 2/0075/16 a ako dopadový ukazovatel’ udržatel’nosti projektu ITMS: 26220120059. 


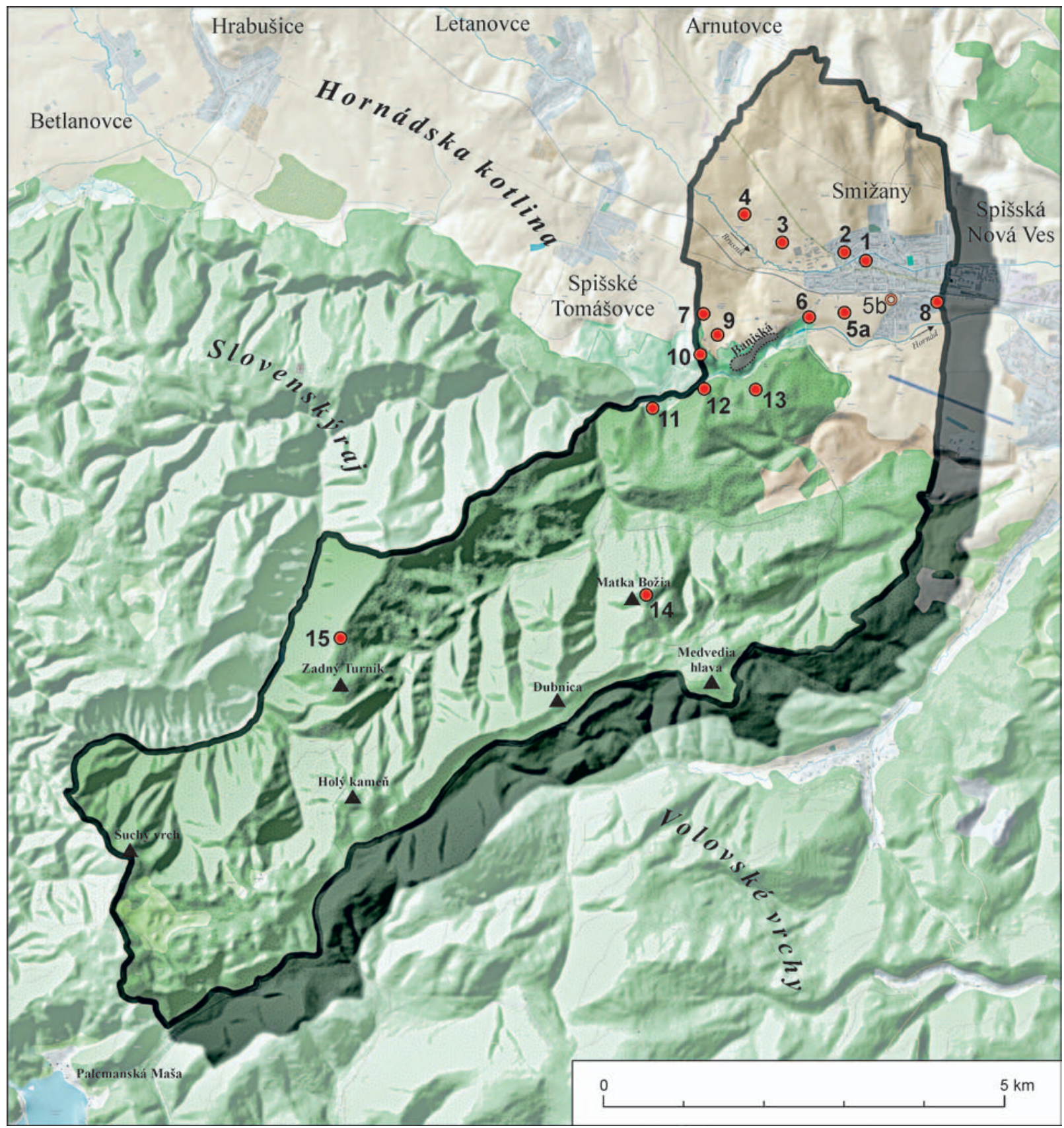

Obr. 1. Smižany. Kataster obce s vyznačenými lokalitami datovanými do obdobia včasného stredoveku. Čísla polôh sa zhodujú s číslovaním lokalít v texte. 1 - OD TESCO; 2 - Ulica kpt. J. Nálepku; 3 - Zlaté role; 4 - Pri kňazovej studni; 5a - Štrkovisko IV; 5 b - Štrkovisko II; 6 - Smižianska Maša; 7 - Gnojník; 8 - Smižianska roveň; 9 - Sedlo pod hradiskom; 10 - Hradisko I; 11 - Hradisko II; 12 - Čingov (Pri starej horárni); 13 - jaskyňa Tri skalky; 14 - Matka Božia; 15 - Turník. Zdroj QGIS, upravil P. Fecko.

137, 138; VSS III 1978, 58). Klimaticky patrí severná, kotlinová čast’ katastra do mierne teplej, mierne vlhkej, pahorkatinovej až vrchovinovej oblasti. Južná, zalesnená čast̉ prináleží už do mierne chladnej a vel’mi vlhkej oblasti (http://klimat.shmu.sk). Táto diverzita je ovplyvnená rozdielnym geomorfologickým členením katastra. Pôdne zloženie (obr. 2: 1, tu podrobnejšie triedenie) tvoria hlavne kambizeme a rendziny. V juhovýchodnej časti katastra sú v menšom rozsahu zastúpené podzoly a v okolí brehov potoka Brusník a rieky Hornád čiernice (Hraško a i. 2017). Smižany patria do lesníckej oblasti Spišskogemerského krasu, v rámci ktorého sa nachádza Národný park Slovenský raj s III. stupňom ochrany. Výmera lesov predstavuje 27,77 ha, kde prevláda okrem iných hlavne buk, smrek, jedla, javor, borovica a smrekovec (LGis 2015). 


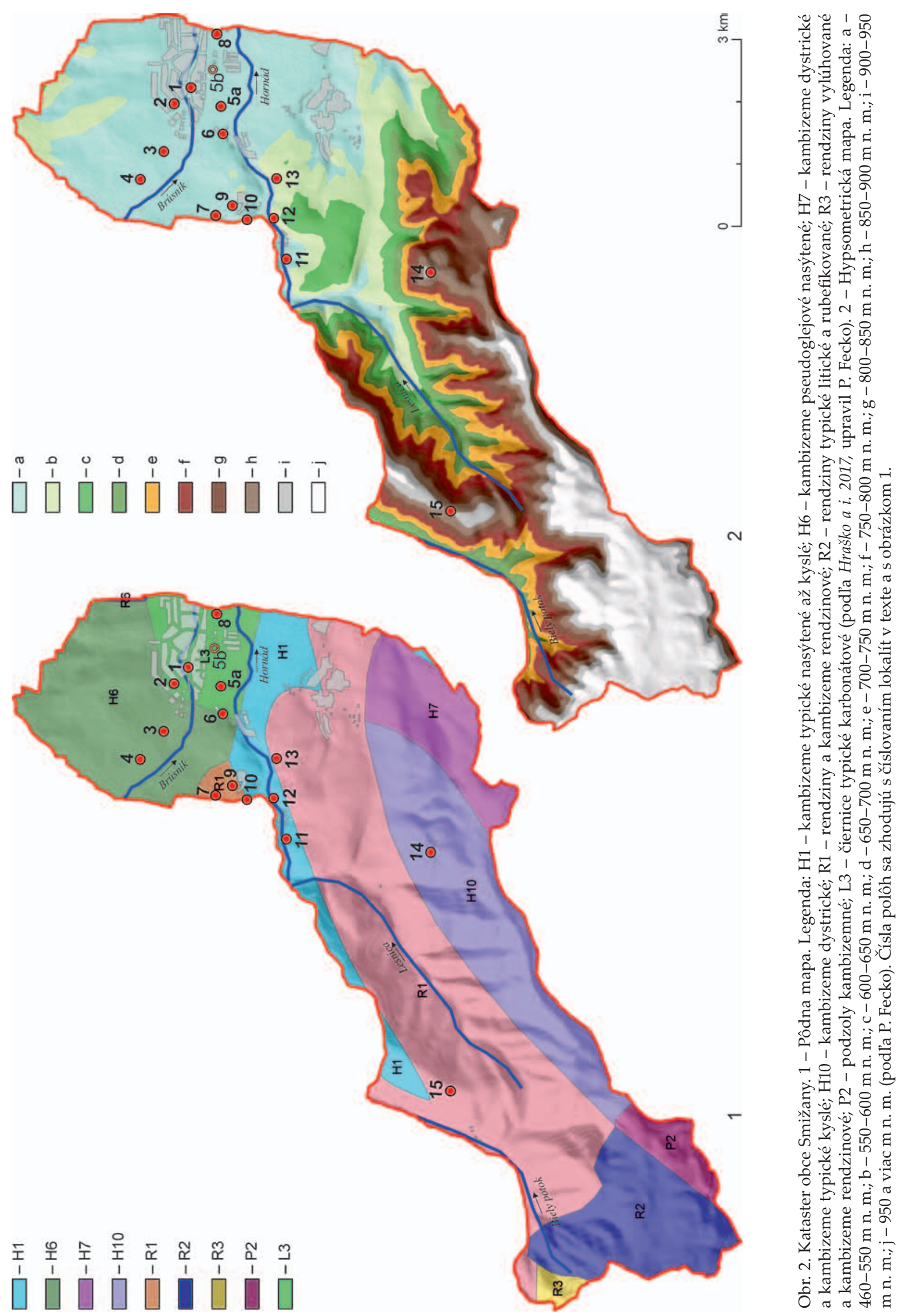


Najstaršia písomná zmienka o Smižanoch pochádza z roku 1246. Išlo o starú obec královských psovodov, ktorá patrila v 13. stor. Spišskému hradu. V severnej časti chotára (asi $280 \mathrm{~m}$ na severovýchod od analyzovaného objektu) stojí rímsko-katolícky ranogotický Kostol Povýšenia sv. Kríža z druhej polovice 13. stor. (Vencko 1941, 37; VSS III 1978, 58).

\section{SITUOVANIE LOKALITY}

Poloha včasnostredovekého sídliskového objektu leží v intraviláne obce na zastavaných plochách západne od centra, priamo pod severným múrom Obchodného centra TESCO pri ulici Javorná (obr. 1; 3). Približne 80 metrov na sever tečie regulovaný potok Brusník. Nadmorská výška v tejto časti územia je $482 \mathrm{~m}$. Táto pahorkatinová čast chotára patrí do Hornádskej kotliny a konkrétne v mieste nálezu prevláda, na území Spiša vel’mi riedko zastúpený, pôdny typ čiernica, ktorý patrí medzi naše najúrodnejšie pôdy (Bielek 2004; Hraško a i. 2017).

\section{PRIEBEH A METÓDA VÝSKUMU}

Sondážny archeologický výskum sa realizoval v troch miestach skúmanej polohy (obr. 3). Sonda I/11 ( $2 \times 5 \mathrm{~m})$ bola umiestnená v juhovýchodnej časti staveniska, v mieste zaniknutej novovekej stavby, z ktorej sa čiastočne odkryla deštrukcia nárožia s početným odpadom (igelity, flaše, konzervy atd’.). Ukázala sa ako negatívna na výskyt archeologických objektov a nálezov. Sonda II/11 $(2$ x 8,5 m) sa situovala približne v strede stavby budúceho obchodného centra TESCO. Hned’ na jej povrchu sa ukázala sterilná vrstva premiešaná s niekdajšou ornicou a s novodobým odpadom. Sonda tiež neposkytla žiadne archeologické objekty a nálezy. Sonda III/11 (3,5 × 6,5 m) ležala na severozápadnom okraji staveniska, v mieste, kde pokusný výkop pre identifikáciu inžinierskych sietí obnažil kultúrnu vrstvu s črepmi (obr. 3-5). Preto sa prikročilo k plošnému odkryvu tejto časti plochy.

\section{OJEDINELÝ SÍDLISKOVÝ OBJEKT}

Ide o pravidelne oválny pôdorys zahĺbenej časti objektu s orientáciou severozápad - juhovýchod (označený ako obj. 1). Kvôli výkopom pre plynovodné potrubie v minulosti sa nezachoval celý pôdorys. Stavebnými prácami narušili jeho južnú a v menšej miere aj východnú čast' (obr. 6). Za západným okrajom objektu sa odkryl zvyšok neznámeho na sucho kladeného múrika, predstavujúceho možno niekdajší chodník (obr. 4: 2; 5; 6). Nakol'ko sa v skladbe chodníka nachádzali medzi kameňmi aj tehly, nepovažujeme ho za súčasný s objektom 1 (Soják/Fecko 2011).

Na základe predpokladu, že ide o pravidelný oválny pôdorys, mohla byt๋ dížka objektu 4,5-5 m a šírka 2,5-3 m, čo predstavuje rozlohu približne $12 \mathrm{~m}^{2}$. Obrysy boli rozpoznané v híbke $60-75 \mathrm{~cm}$ od súčasného terénu, kedy sa začali rysovat’ ako čierna plocha na sterilnom svetložltom podloží (obr. 4: 1). Po doskúmaní dosahoval híbku $95 \mathrm{~cm}$ od terajšej úrovne povrchu. Zahĺbenie do sterilného podložia predstavovalo 20 až $30 \mathrm{~cm}$.

Na základe typológie $P$. Šalkovského $(2001,18)$ radíme objekt k jeho typu 3. Tie zastupujú zemnice oválneho, obličkovitého alebo nepravidelného tvaru s misovitým zahĺbením. Pre konkrétny typ navrhuje spomenutý autor termín: "dom s čiastkovo zahíbeným interiérom" (Šalkovský 2007a, 302) či obšírnejšie „stavby s hybridným princípom riešenia interiéru, ktorých značná čast” plochy interiéru, zväčša centrálne situovaná a vybavená kúreniskom, bola zahĺbená (zväčša viac ako $20 \mathrm{~cm}$ ) v zemi a zvyšok interiéru po stranách centrálnej jamy zahĺbený nebol" (Šalkovský 2011b, 174). Ich zahĺbenie sa pohybovalo väčšinou od 40 do $80 \mathrm{~cm}$, a rozloha od 4 do $8 \mathrm{~m}^{2}$. Väčšia rozloha $\left(9-12 \mathrm{~m}^{2}\right.$ ) sa uvádza ako menej častá (Šalkovský 2001, 42; 2007a, 302). Typické pre tento typ zemníc je, že v nich prevládajú (65-80\%) otvorené ohniská obkolesené kameňmi (Šalkovský 1983, 119; 1998, 14; 2001, 55; 2002, 59; 2007a, 302). Poznáme ich hlavne zo 7.-8. stor. (Šalkovský 2001, 56; 2011a, 21; z hladiska konštrukcie, funkčnosti a pôvodu pozri (Šalkovský 1983, 120; 2009a, 40, 41, 43). Výrazne sa viažu najmä na horské územia stredného a východného Slovenska, Moravy i Čiech (Šalkovský 2007a, 301, 304; 2011a, 19). 

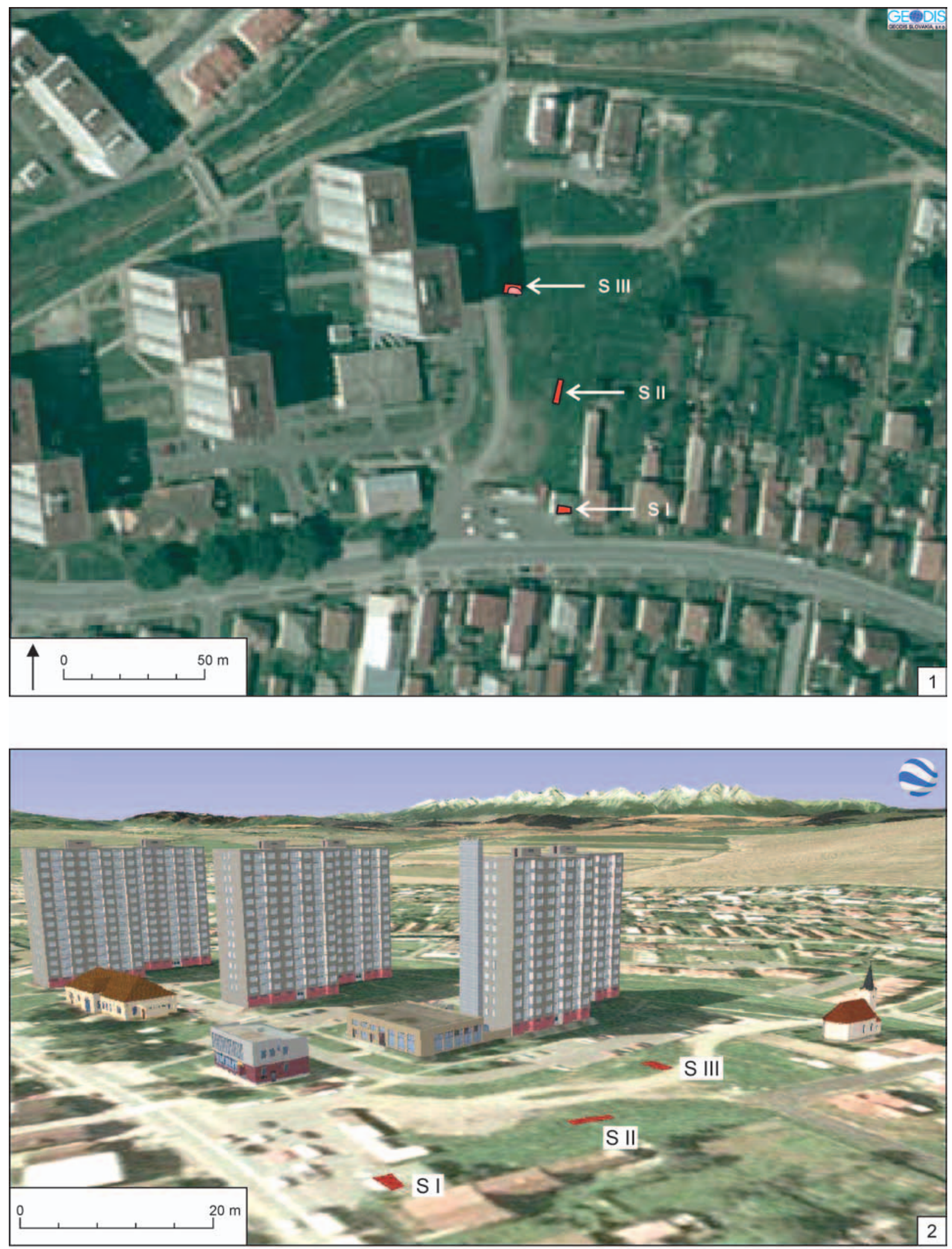

Obr. 3. Smižany, poloha OD TESCO. 1 - situovanie archeologických sond I - III z roku 2011 na ortofotomape; 2 - situovanie archeologických sond I - III na 3D zobrazení. Zdroj Google Earth. 

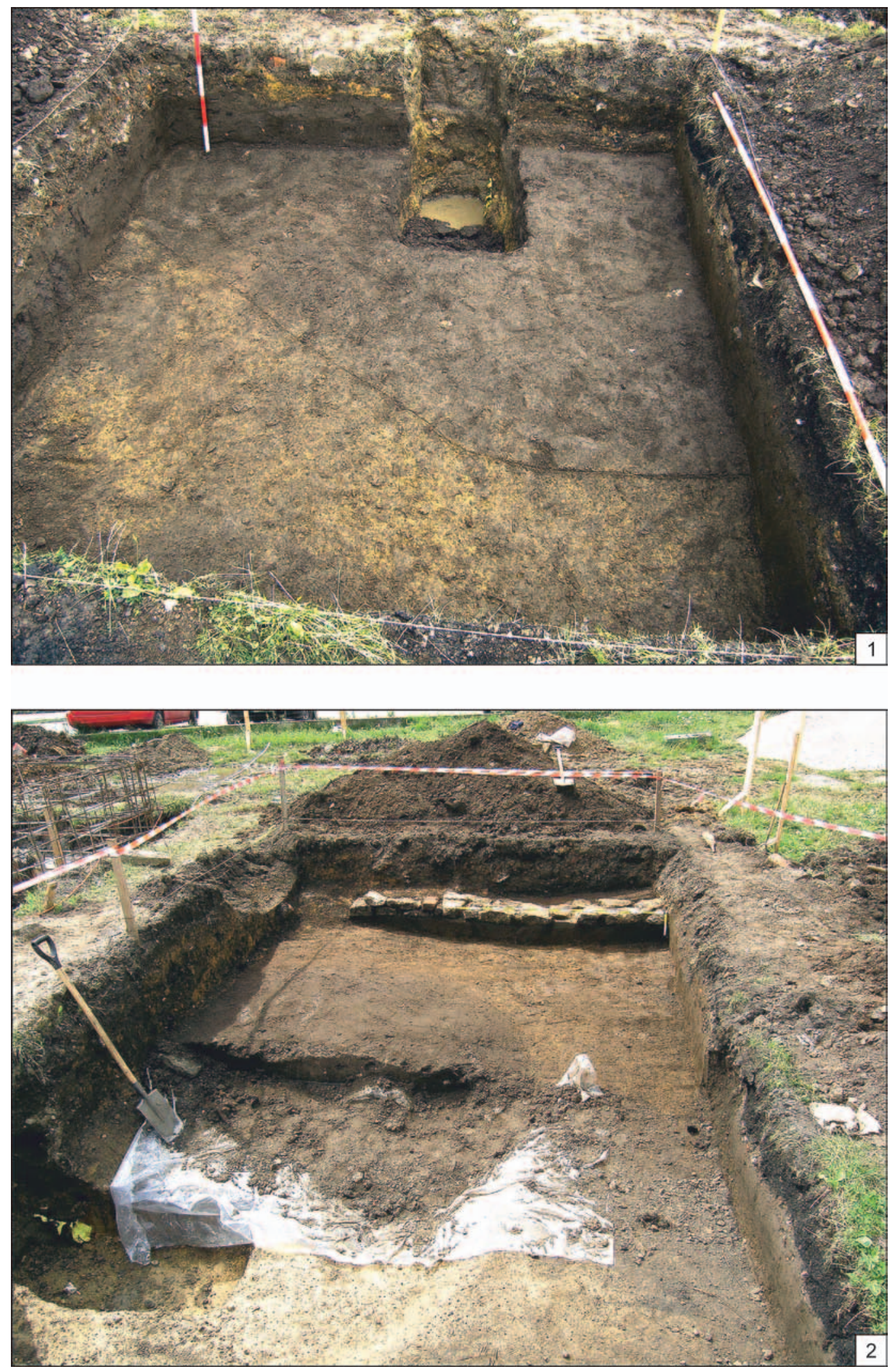

Obr. 4. Smižany, poloha OD TESCO, sonda III/11, obj. 1.1 - zachytená juhovýchodná čast’ objektu v híbke $70 \mathrm{~cm}$ od úrovne súčasného terénu; 2 - rozširovanie objektu západným smerom. 

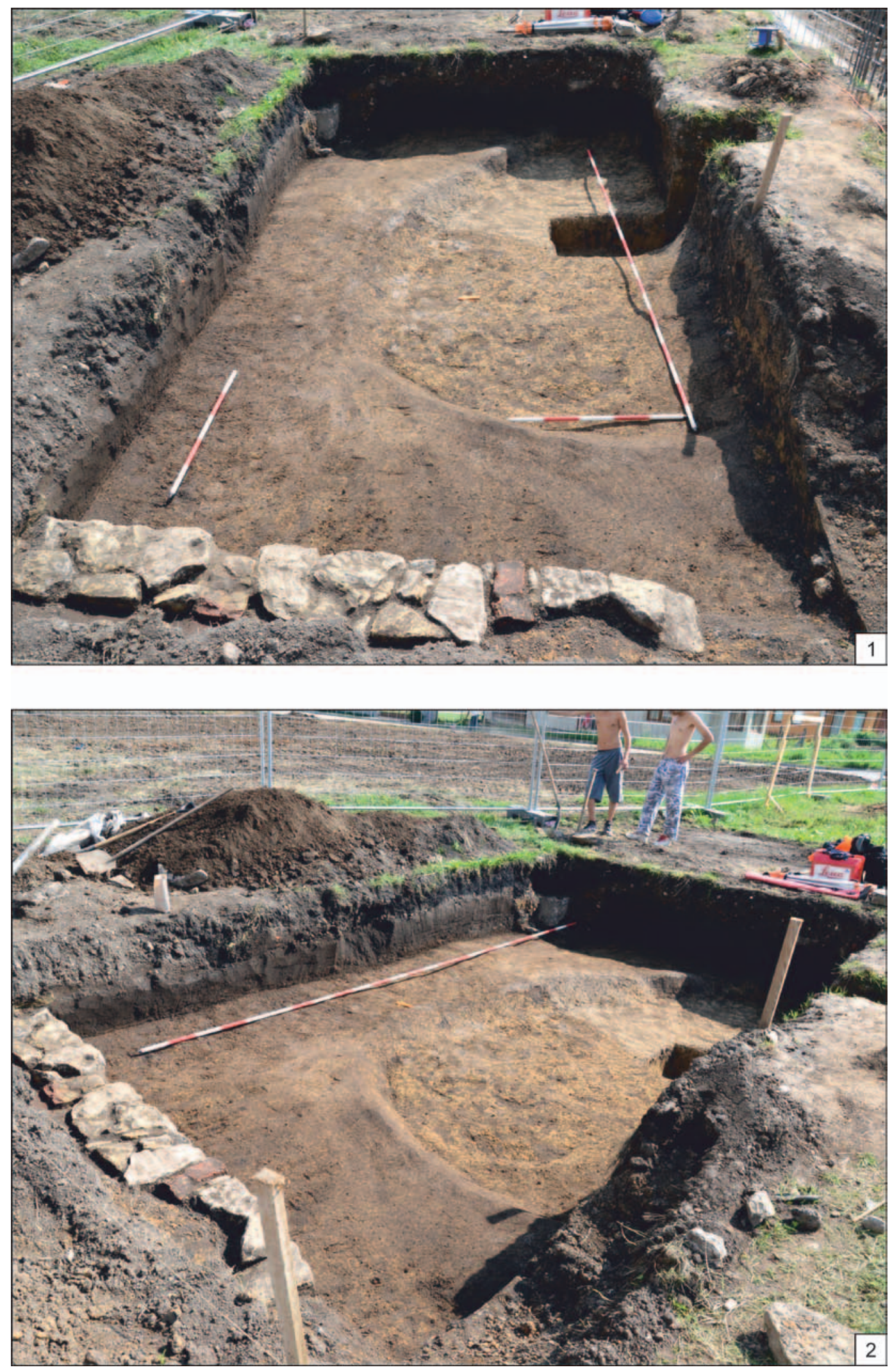

Obr. 5. Smižany, poloha OD TESCO, sonda III/11, obj. 1. 1, 2 - pohl'ad na preskúmaný objekt. 

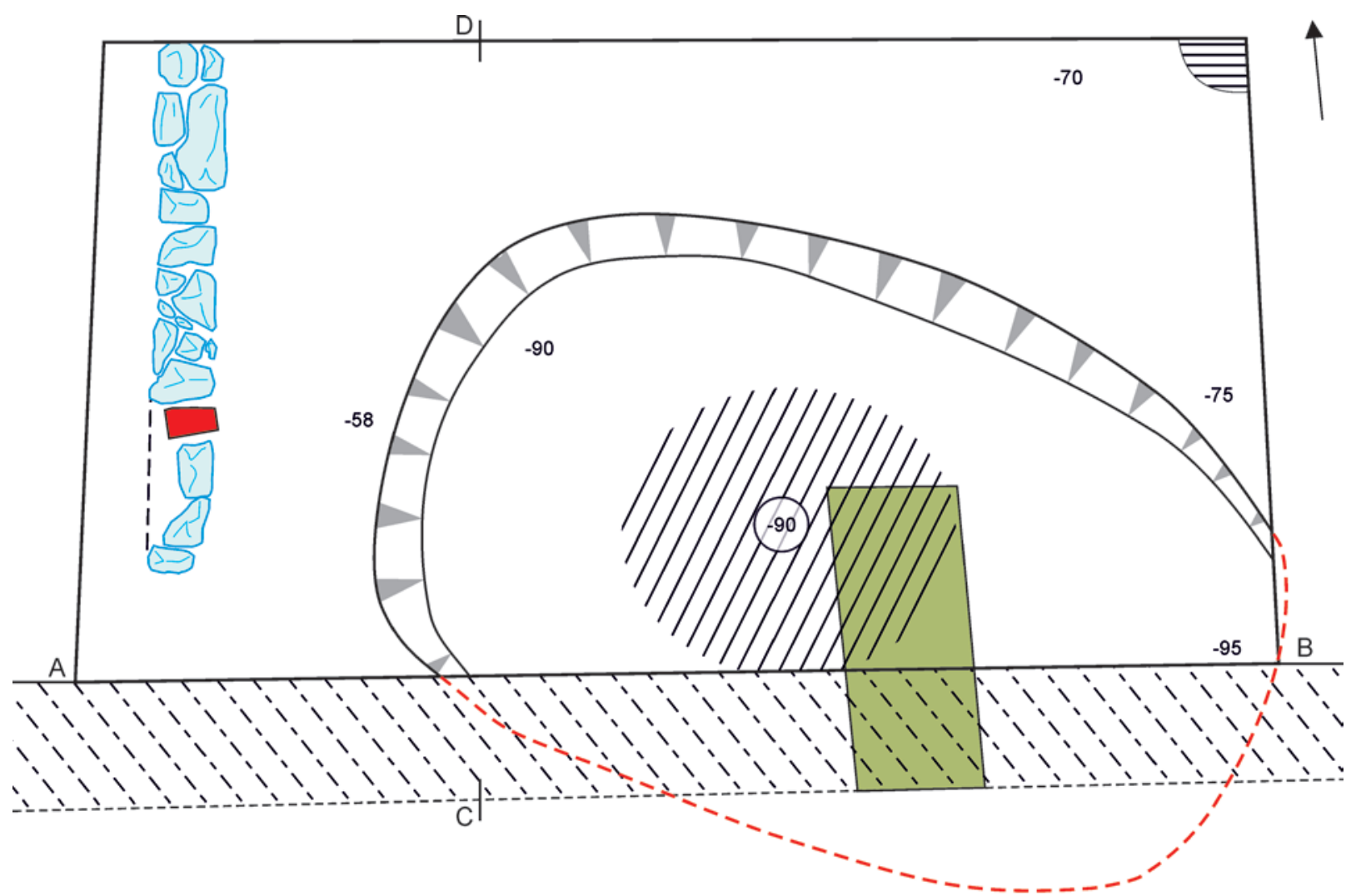

0

B
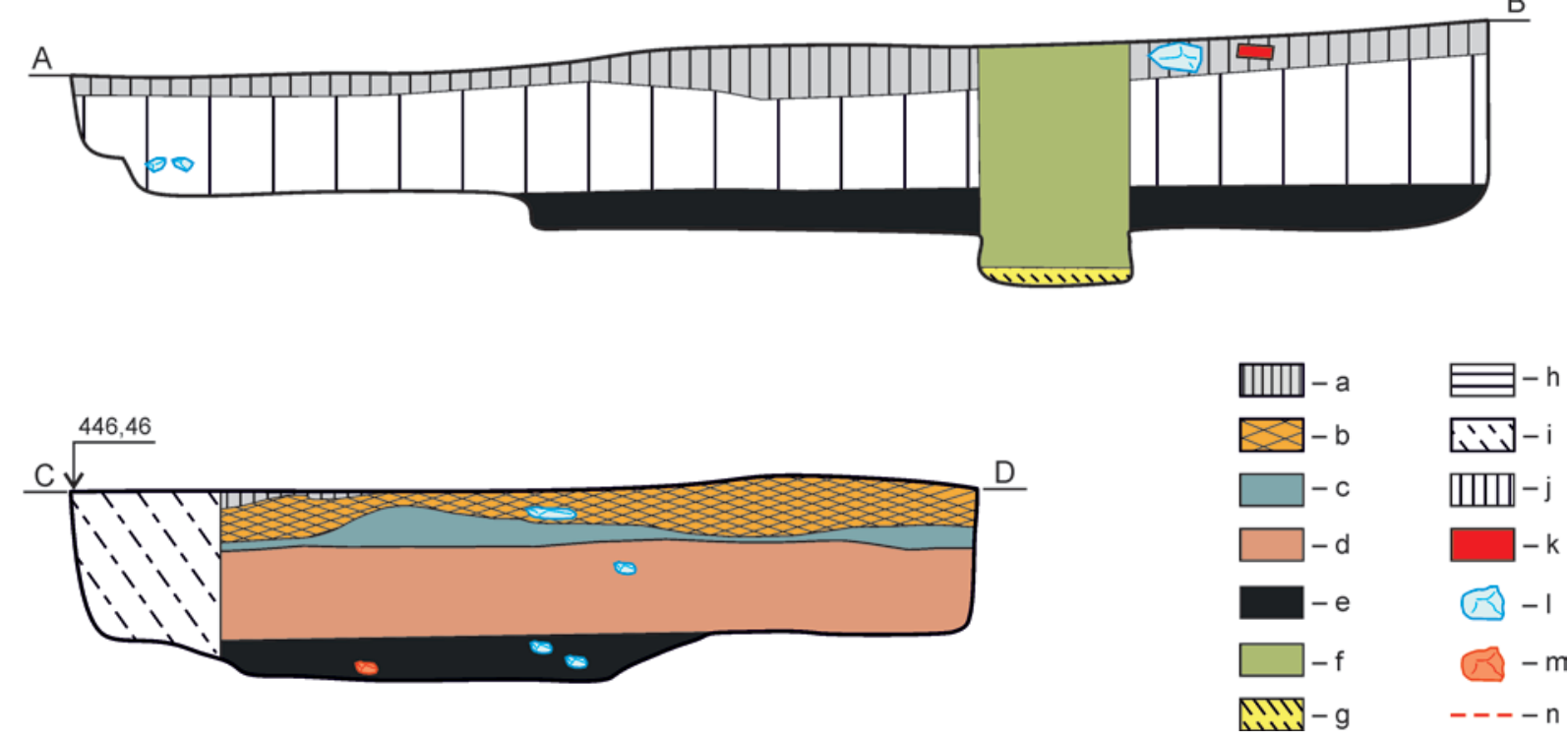

Obr. 6. Smižany, poloha OD TESCO, sonda III/11, obj. 1. Pôdorys a profily po vybratí na sterilné podložie. Legenda: a - vrchná vrstva tmavočiernej zeminy premiešanej menšími fragmentami štrku a korením trávnatej vegetácie; b - tmavočierna škvara premiešaná novovekým odpadom a štrkom; c - sivá až sivohnedá zemina premiešaná novovekými tehlami a štrkom (navážka); d - kultúrna pôda hnedého sfarbenia, kompaktná s koncentráciou archeologických nálezov z novoveku a včasného stredoveku; e - objekt 1 . Tmavočierna pôda, kompaktná s koncentráciou včasnostredovekých archeologických nálezov; f - zistovacia sonda vykopaná stavbármi za účelom hl’adania plynovodného potrubia; g - žltá fólia umiestnená nad plynovodným potrubím; h - vodárenská betónová skruž; i - ryha plynovodného potrubia; j- okraj ryhy pre plynovodné potrubie, sterilná zemina premiešaná s ornicou; $\mathrm{k}$ - fragmenty novovekých tehál; 1 - pieskovcový kameň; m - prepálený pieskovcový kameň; n - predpokladaný priebeh objektu. Kresba P. Fecko. 
V súčasnosti už vieme, že prví Slovania, prichádzajúci na územie Spiša v druhej polovici 6. stor., stavali typické kvadratické zemnice (Fecko a i., v tlači; Kučerová a i. 2012, 21 n.). Do úvahy prichádzajú dve teórie týkajúce sa zmeny typu obydlia vo vyššie spomenutých oblastiach. Prvá môže súvisiet so samotnými prírodnými pomermi, ktoré ovplyvňovali okrem iného aj architektúru stavieb (Fecko 2016, 53, 55; Śalkovský 1980, 166; 2002, 62). Kvadratické zemnice sa pravdepodobne neosvedčili ako vhodné pre tunajšie klimatické a pôdne podmienky. Preto nastala zmena v typoch obydlia. Túto môžeme vidiet $\mathrm{v}$ zatial' ešte nepublikovaných nepravidelne oválnych objektoch, rámcovo datovaných na základe keramiky do prvej polovice 7. stor. ${ }^{2}$, objavených v Spišskej Novej Vsi v polohe Pod Modrým vrchom v rokoch 2016 a 2017 (objekt 91, 92, 93), prípadne na lokalitách Blatné Remety, Dvorianky, Vranov nad Toplou-Lomnica (Budinský-Krička 1990, 92 nn.). Druhou teóriou môže byṫ predpoklad o prenikaní Slovanov na Spiš z južných oblastí Slovenska, ktorí si so sebou priniesli aj zaužívaný typ zemníc odniekial' z juhovýchodných stepných oblastí (Šalkovský 2001, 42, 54). Pravdepodobne niektorým skupinám nevyhovovala nepokojná situácia vyvolaná príchodom Avarov do Karpatskej kotliny v druhej polovici 7. a začiatkom 8. stor. V tom čase dochádza k expanzii avarského kaganátu na sever (Nevizánsky 1991, 138; Ruttkayová 1991, 196; Zábojník 2002, 32 n.), a tým pravdepodobne aj k presunom tamojšieho obyvatel'stva do pokojnejších oblastí severného Slovenska, ktoré neboli vhodné pre nomádsky spôsob života. Ako jedna z možných trás mohla vieste údolím rieky Slanej cez Spišsko-gemerské rudohorie (Javorský 1993, 22). S touto druhou teóriou môže súvisiet tiež výskyt zdobenia vnútornej strany okrajov ústia na nádobách. Tento dekoračný element sa v hojnej miere vyskytuje na území kontaktnej zóny s avarským kaganátom v južnejších častiach Slovenska (napr. Béreš 1985, 32; Čilinská 1966, 132; 1973; Galuška 1987, 77; Vendtová 1964, 365; Zábojník 2004, 65) a na sever sa mohol dostat práve z dôvodu vyššie opísanej situácie.

\section{POKUS O REKONŠTRUKCIU OBJEKTU}

Vychádzajúc z podrobných analýz P. Šalkovského ${ }^{3}(1998,14 ; 2001,18,42,55,56 ; 2007 a ; 2009 b, 278,279)$ týkajúcich sa včasnostredovekých sídliskových objektov interpretujeme objekt 1 ako zemnicu s l’ahšou zrubovou či rámovou konštrukciou v nadzemnej časti. Zachovaný pôdorys zemnice, ktorá sa rysovala na sterilnom podloží ako obdĺžniková jama, bola zrejme iba centrálnou častou stavby, okolo ktorej mohli byt’ situované lôžka a iné odkladacie priestory. Samotné rozmery a tvar zemnice mohli byt๋ teda rozsiahlejšie ak vychádzame z predpokladu, že nízke zrubové steny alebo iba strechu umiestnili približne $1 \mathrm{~m}$ zvonku zachovanej jamy. To umožnilo podstatne zväčšit využitú plochu interiéru, ktorá mohla dosahovat’ aj dvojnásobok archeologicky zistenej plochy (Šalkovský 2001, 42; 2007a, 301, 307; 2011a, 19). Uvažuje sa o dvojspádovej sedlovej forme strechy, ktorá bola opretá bud’ o zem (Šalkovský 2007a, obr. 2: 1) alebo osadená do drevených stien vybudovaných okolo centrálnej jamy (Šalkovský 2007a, obr. 2: 2; 2009a, 43; 2011a, 21). Interiér mohol obsahovat’ aj ohnisko obložené kameňmi (Šalkovský $1998,14)$ aké sa našli napríklad v podobných objektoch 73 a 87 v Spišských Tomášovciach/Smižanoch na Hradisku I (Béreš/Šalkovský 1978, 37). Podla nájdeného inventára vylučujeme jeho funkciu ako hospodárska stavba. Aj ked' čast týchto stavieb bez vykurovacieho zariadenia je považovaná za vedlajšie stavby, prístrešky alebo pivničky (Šalkovský 2002, 65; 2007b, 116; 2011b, 174), v našom prípade predpokladáme obytný charakter objektu. Indikuje to najmä charakter nájdených artefaktov (keramika, praslen, kamenné brúsiky, kostené šidlá a podobne). Absencia ohniska môže súvisiet’ s tým, že nebol zachytený celý pôdorys objektu a ohnisko sa mohlo nachádzat’ v už zničenej (južnej) časti. Podl’a doterajších výskumov zemníc sú však ohniská situované v ich zahĺbených častiach (Šalkovský 2007a, 302). Podobný prípad absencie ohniska v obytnom objekte poznáme $\mathrm{z}$ vel'komoravského sídliska v Branči, kde v objekte 157 nebol zaznamenaný žiadny typ výhrevného zariadenia (Hanuliak/Vladár 2008, 88 n., obr. 4: 2). Autori príspevku uvádzajú, že takéto objekty mohli slúžit na príležitostné prespávanie, alebo na dlhodobejšie obývanie v čase núdze (Hanuliak/Vladár 2008, 90). Nemožno vylúčit, že je to tiež prípad sledovaného objektu zo Smižian.

Výskyt zemníc typu 3 je zväšša geograficky podmienený. Na území Slovenska sú rozšírené hlavne na východe a na Záhorí (Šalkovský 1983, 120, 127; 2002, 59). Najbližšiu analógiu nachádzame v už

\footnotetext{
2 Nálezy z výskumu M. Sojáka v r. 2016-2017. Za konzultácie ohladom chronologického zaradenia keramiky d’akujeme G. Fusekovi.

3 Hlavne príspevok o obdĺžnikovitých a oválnych zemniciach s obsiahlou použitou literatúrou (Šalkovský 2007a).
} 
spomenutých Spišských Tomášovciach/Smižanoch na Hradisku I. Na plochách priliehajúcich k valu boli preskúmané okrem iných aj dva objekty 73 a 87, datované do druhej polovice 8 . až prvej polovice 9 . stor. (Béreš/Šalkovský 1978, 37; Staššíková-Štukovská a i. 2006, 201; Šalkovský 1983, 127; 2007b, 114, 118). Podobné typy obydlí sa našli napríklad na nasledovných lokalitách: Vranov nad Toplou, poloha Lomnica, obj. 4/79 (Budinský-Krička 1990, 97, obr. 7), Blatné Remety, obj. 4 (Budinský-Krička 1990, 92, obr. 2: 1), Parchovany, obj. 1/81 datovaný podla keramiky hlavne do 9. najneskôr do 10. stor. (Budinský-Krička 1982, 51-53, 348, obr. 41).

\section{KERAMIKA}

Z objektu 1 pochádza spolu 216 fragmentov z hrncovitých nádob s jednoducho esovite profilovaným nižším ústím. Tie boli vyhotovené obtáčaním na pomaly rotujúcom ručnom hrnčiarskom kruhu. Ide väčšinou o hrubostenné, dobre vypálené zlomky s prímesou piesku a sludy, s drsnou štruktúrou vonkajšieho povrchu. Najpočetnejšie pochádzajú z tela nádob, predstavujú $67 \%$ z celkového súboru, okraje tvoria $11 \%$, dná $9 \%$, zlomky z pliec nádob $8 \%$ a hrdlá $5 \%$. Z nich možno identifikovat minimálne 12 typov nádob (obr. 7-10: 1-3), pritom sa jedna dala komplexne zrekonštruovat' (obr. 7: 1; 12: 2). Na základe zachovaných tvarov ide o hrncovité nádoby s vajcovitým telom a najväčšou vydutinou v hornej tretine s viac či menej vyhnutým ústím jednoduchej profilácie.

\section{Okraje}

Podla nájdených 24 kusov fragmentov možno rozpoznat tri typy a ich varianty. ${ }^{4}$

Typ A - zaoblená vonkajšia strana okraja:

variant A1 - jednoduchý zaoblený okraj (10 ks: obr. 8: 1; 9: 1; 10: 1, 4-8, 13),

variant A2 - zaoblený, vytiahnutá spodná hrana (3 ks: obr. 7: 2; 8: 2; 10:3),

variant A3 - zaoblený, na vnútornej strane okraja s nevýrazným žliabkom (1 ks: obr. 10: 10);

Typ B - zrezaná vonkajšia strana okraja:

variant B1 - jednoducho, šikmo zrezaný, kužel'ovitý okraj (6 ks: obr. 7: 1; 8: 3; 9: 4; 10: 2, 9),

variant B2 - šikmo zrezaný, spodná hrana v tvare lišty (1 ks: obr. 9: 2),

Typ C - vonkajšia strana so žliabkom so spodnou lištou (1 ks: obr. 9: 3).

\section{Dná}

Zastúpené sú 18 kusmi z celého keramického súboru. Pri ich morfologickom triedení sa opierame o delenie podla prierezu podstavy, ako je to už preferované u väššiny autorov (Fusek 2009, 102-106; Odler/Kolník 2011, 73; Odler/Zábojník 2011, 148). Na základe tohto triedenia majú v spomínanom súbore prevahu hlavne dná (10 ks), ktoré neboli dostatočne zachovane nato, aby sa dal určit celý tvar podstavy. Ostatných 8 ks (obr. 11: 21-27; 12: 1) má klenutú podstavu bez prstenca. Predpokladáme, že ku preklenutiu došlo pri sušení nádoby, ktorá bola otočená hore dnom (Fusek 2008, 25; 2009, 102). Ak by klenutie spôsobil drevený kotúčik (Fusek 2009, 99, 102), ktorý sa kládol na dosku hrnčiarskeho kruhu, kvôli lepšiemu odseparovaniu nádoby, tak by na dnách bolo badat' stopy po prstencoch. Tie sa nezistili ani v jednom prípade. Na dvoch fragmentoch sa zachovali odtlačky po oske kruhu (obr. 11: 21; 12: 1). Na dne sa vyskytujú ako individuálne, neúmyselne odtlačky (po rastlinách), tak technologické odtlačky náhodné, napr. v podobe zárezov súvisiacich so snímaním nádoby z kruhu. Otlačky osky kruhu súvisia s technickou stránkou výroby, preto ich nepovažujeme za úmyselne vyhotovené značky (k tomu napr. Béreš 1995, 149, 150).

\section{Výzdoba}

Pokial ide o počet, prevažovali črepy bez výzdoby. Z hladiska výzdobných motívov prevažuje hrebeňová výzdoba v podobe viacnásobnej vlnovky (39 ks; obr. 7-10). Z ostatných motívov sa vyskytujú

\footnotetext{
4 Jeden fragment sa nedal bližšie identifikovat.
} 

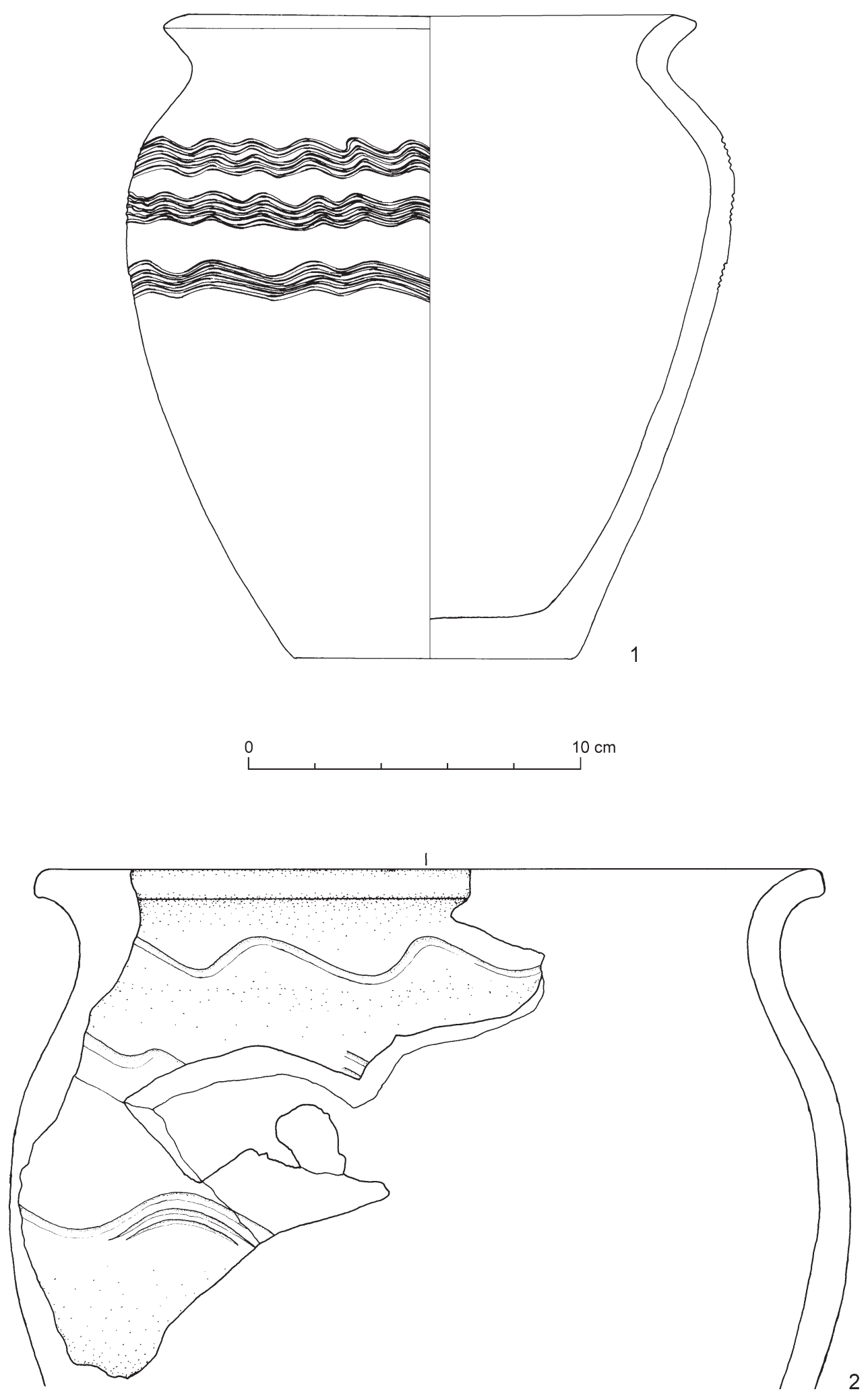

Obr. 7. Smižany, poloha OD TESCO, sonda III/11, obj. 1. Výber keramických nálezov. Kresba 1 - E. Bakytová; 2 - P. Fecko. 

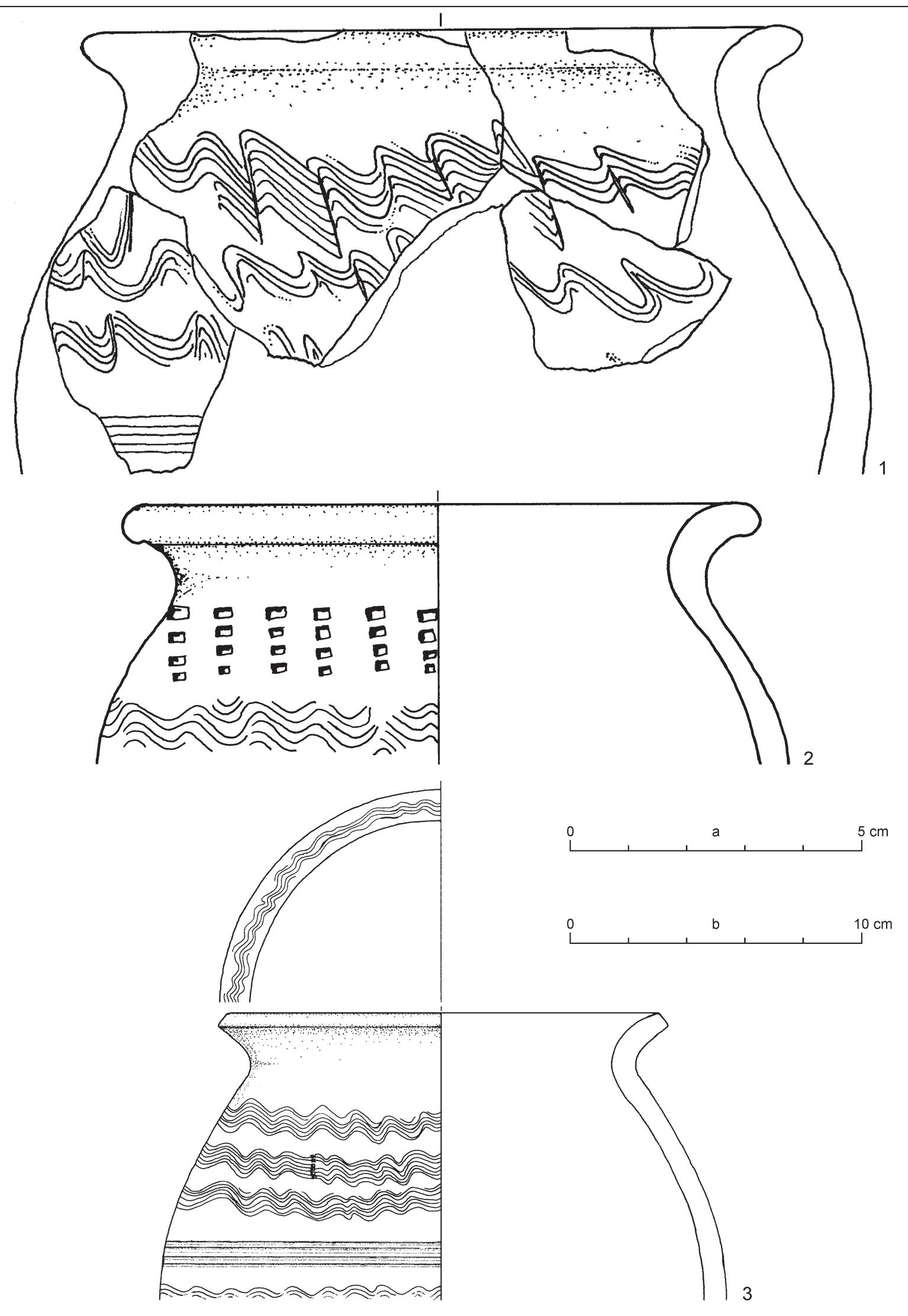

Obr. 8. Smižany, poloha OD TESCO, sonda III/11, obj. 1. Výber keramických nálezov. Mierka: a - 1, 2; b - 3. Kresba P. Fecko. 

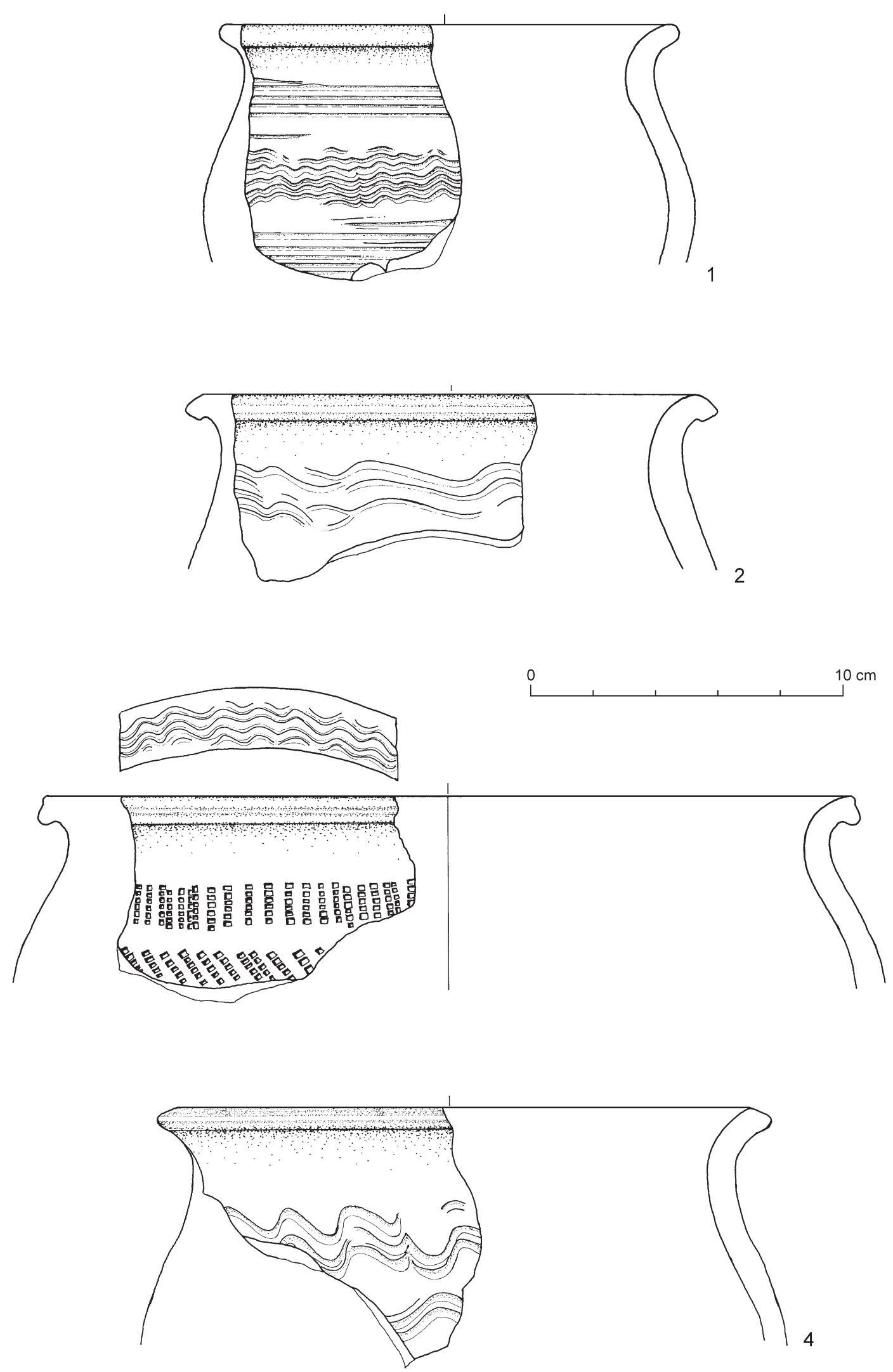

Obr. 9. Smižany, poloha OD TESCO, sonda III/11, obj. 1. Výber keramických nálezov. Kresba P. Fecko. 

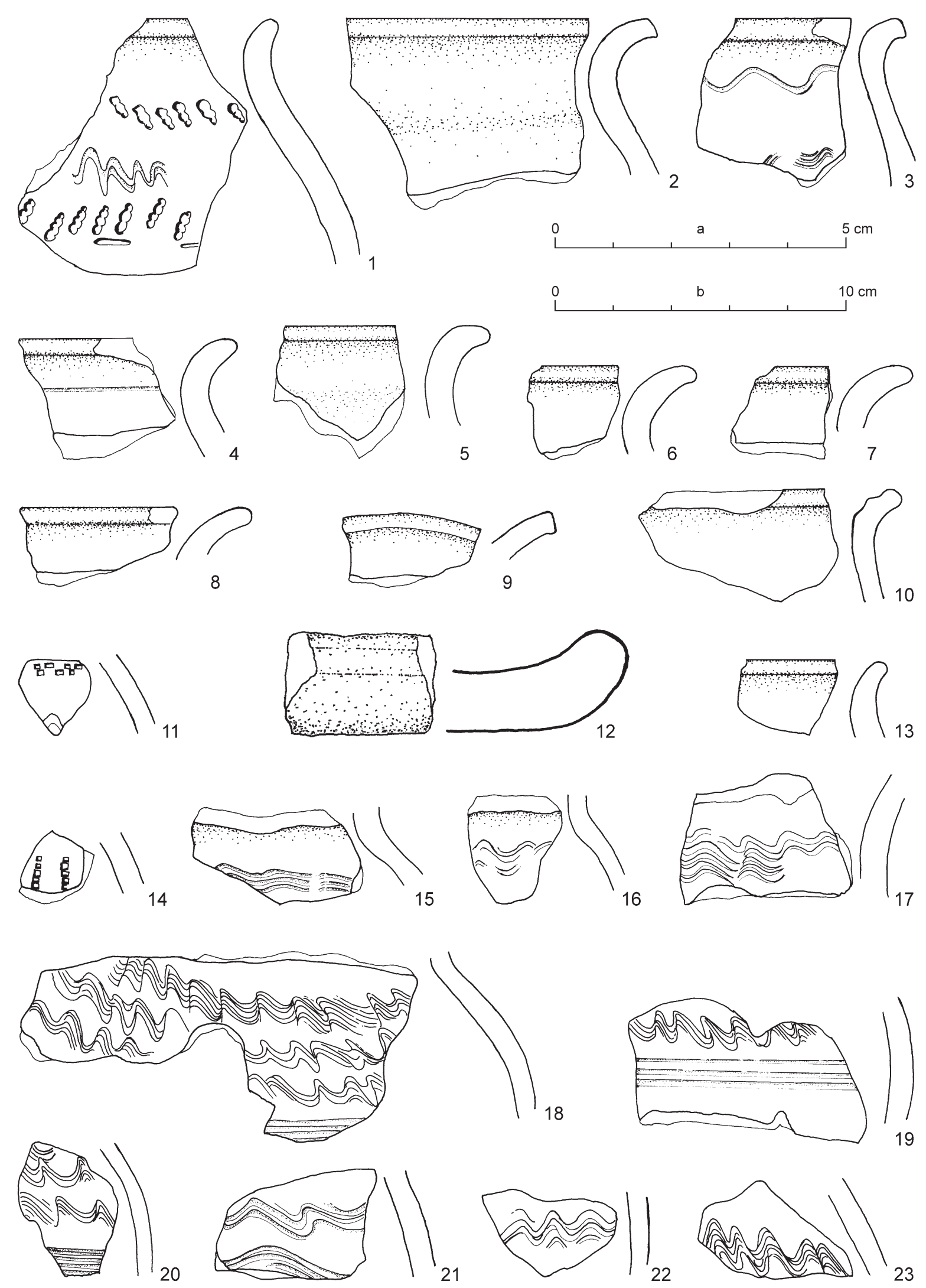

Obr. 10. Smižany, poloha OD TESCO, sonda III/11, obj. 1. Výber keramických nálezov. Mierka: a - 12; b - 1-11, 13-23. Kresba P. Fecko. 

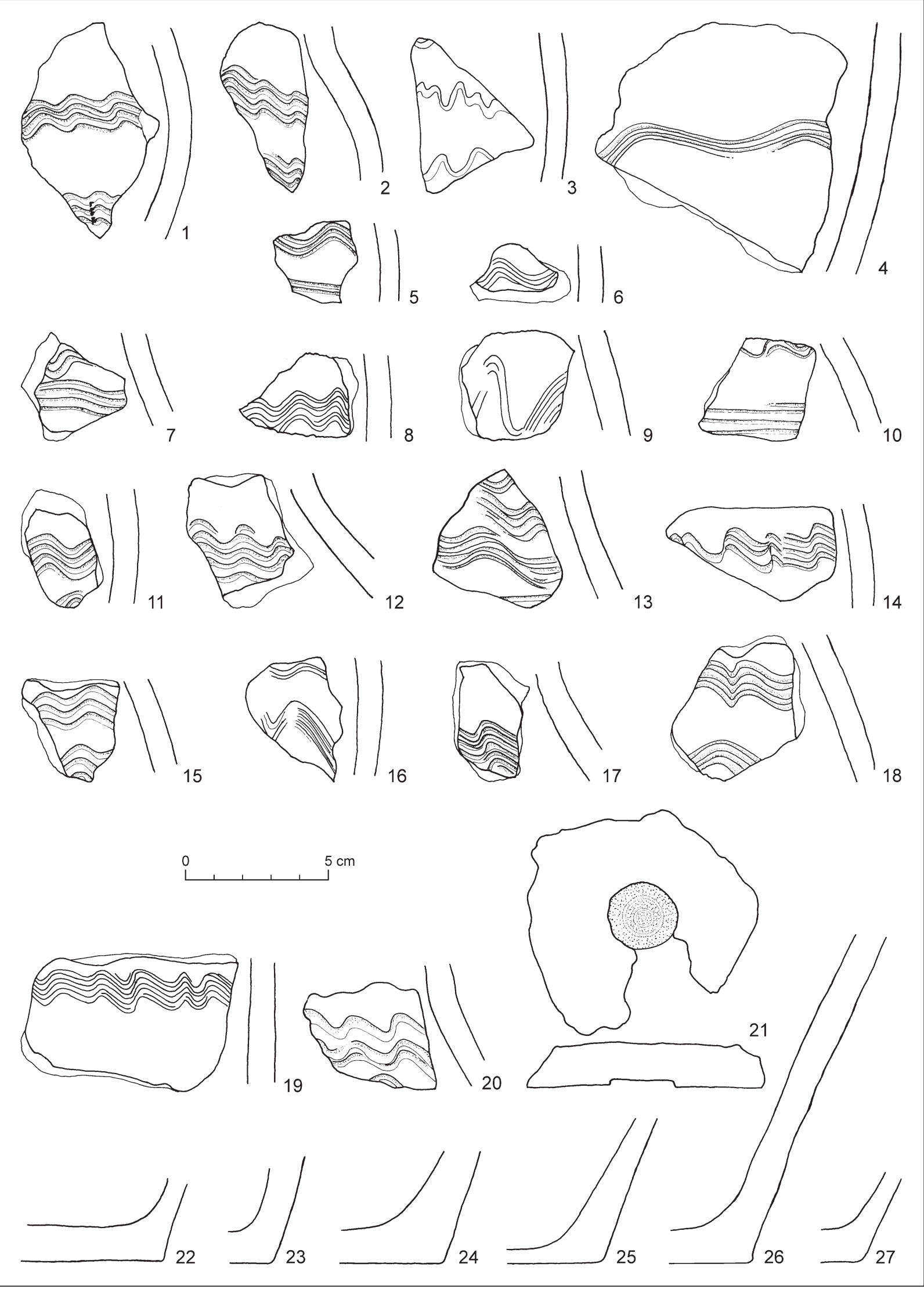

Obr. 11. Smižany, poloha OD TESCO, sonda III/11, obj. 1. Výber keramických nálezov. Kresba P. Fecko. 


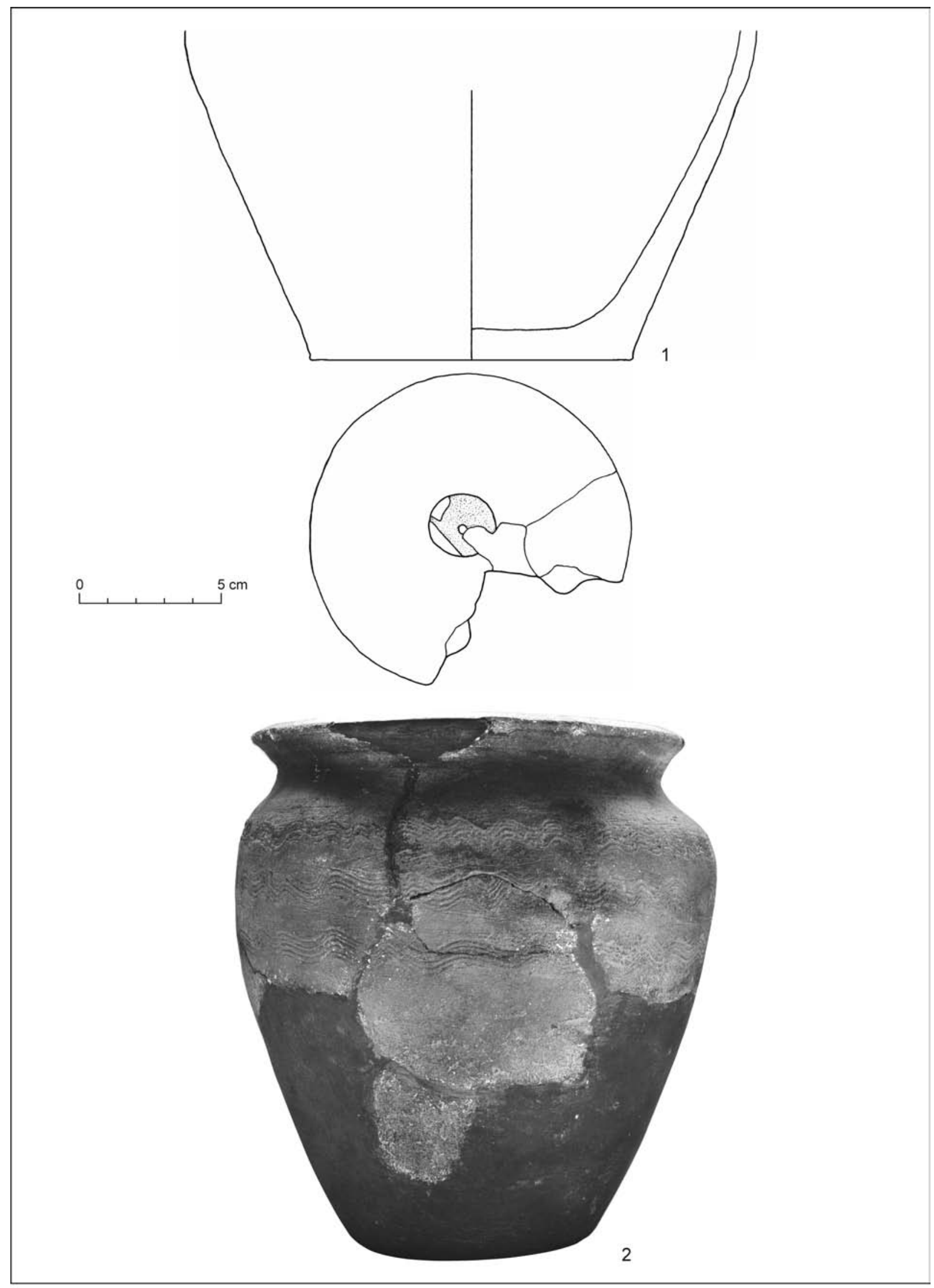

Obr. 12. Smižany, poloha OD TESCO, sonda III/11, obj. 1. Výber keramických nálezov. Kresba a foto P. Fecko. 
viacnásobné ryté obežné línie (6 ks), jednoduchá vlnovka robená jednohrotým nástrojom alebo koncom hrebeňa $(9 \mathrm{ks})$ a hrebeňový vpich $(4 \mathrm{ks})$. Zlomkovitost̉ nájdených fragmentov keramiky nám až na jeden prípad (obr. 7: 1; 12: 2) nedovoluje zistit úplnú kompozíciu výzdobných prvkov na nádobách. Častá je kombinácia viacnásobných obežných línií s viacnásobnou vlnovkou (11 ks; obr. $8: 1,3 ; 9: 1 ; 10: 18-20)$. Tá je bežná pre obdobie 8 . -9. stor. a evidujeme ju na viacerých súvekých sídliskách na Slovensku (Béreš/Odler 2011, 15; Fusek 1994a, 64; 2008, 25; Hanuliak 2015, 126; Odler 2014, 41-42; Odler/Kolník 2011, 74, 82: Tabela 6; Odler/Zábojník 2011, 149; Rejholcová 1977, 654; Ruttkayovál Ruttkay 2004, 325; Šalkovský 2011a, 45, 48; 1994, 168). Iba v dvoch prípadoch sa našla kombinácia výzdoby viacnásobnej vlnovky a hrebeňového vpichu (obr. 8: 2; 10:1). V menšom počte sa vyskytli kombinácie jednoduchej vlnovky a viacnásobných vlnoviek (obr. 7: 2; 10: 3) alebo tiež jednoduchej vlnovky s hrebeňovým vpichom (obr. 10: 11). Na menších črepoch sa kombinácie výzdobných motívov nedali spolahlivo interpretovat'. Pravidelnost̉ nanášaných ornamentov je plynulá. Robila sa pomocou hrebeňa so štyrmi až šiestimi, prevažne tenšími zubmi. Vpichované motívy sú jednoduché a skladajú sa z pásov zvislo či mierne šikmo radených rôzne hustých vpichov (obr. 8: 2; 9: 3; 10: 1, 11, 14). Vetvičkový motív možno predpokladat iba $\mathrm{v}$ jednom prípade, no nezachovala sa celá čast' výzdoby (obr. 9: 3). Pri vytváraní motívov či už vlnoviek, obežných línií alebo vpichov používal hrnčiar ten istý hrebeňovitý nástroj. Počet odtlačených zubov je rozdielny (Béreš/Odler 2011, 16; Fusek 1994a, 64; Hanuliak 2015, 126; 2016, 111, 115) a záležal od toho, v akej časti hrnca sa výzdoba aplikovala a rovnako aj podla toho ako bol nástroj pri zdobení naklonený, pretože morfológia nádoby nie vždy dovolovala odtlačit všetky zuby hrebeňa na povrch. V dvoch prípadov bola vnútorná strana ústia zdobená vlnovkou (obr. 8: 3; 9: 3).

Okrem hrncovitých nádob bol v jednom prípade identifikovaný aj keramický fragment pekáča (obr. 10: 12). Ide o plytký nezdobený okraj čiernej farby. Na povrchu badat stopy po ručnom formovaní. Pekáče slúžili na tepelnú úpravu stravy na ohniskách alebo v pieckach a sú typické pre Slovanov na celom území ich rozšírenia v dlhom časovom úseku (Béreš 1985, 46; Fusek 1991, 309, 310; 1994a, 77). Nálezy podobných fragmentov poznáme napr. z lokalít Vel'ké Trakany (Budinský-Krička 1990, tab. XXVII: 1; XXVIII: 17-25) alebo Hurbanovo-Bohatá (Rejholcová 1977, 654).

\section{Opis zachovanej nádoby}

Ide o hrncovitú nádobu vajcovitého tvaru s najväčšou vydutinou v hornej tretine. Okraj je mierne von vyhnutý s kužel’ovitým zrezaním. Telo pokrýva výzdoba zložená z troch radov viacnásobných vlnoviek, ktoré začínajú na pleciach. Aplikovaná bola päthrotým hrebeňovitým nástrojom. Výška nádoby je $19 \mathrm{~cm}$, vonkajšia šírka ústia $16 \mathrm{~cm}$, vnútorná šírka ústia $12 \mathrm{~cm}$, maximálna šírka pliec 18,5 cm, priemer dna je $9 \mathrm{~cm}$ (obr. 7: 1; 12: 2). Pri ostatných fragmentoch horných časti nádob, ktoré sa dali kresbovo zrekonštruovat', sa priemer vonkajšieho ústia pohybuje od $11 \mathrm{~cm}(\mathrm{obr}$. 8: 2) do $26 \mathrm{~cm}$ (obr. 9: 3), čo v priemere predstavuje šírku $17 \mathrm{~cm}$.

Zhodné štýlové prvky s keramikou nájdenou v polohe TESCO z objektu 1 nachádzame v rôznych častiach Slovenska, či už ide o horské oblasti alebo nížiny (napr. Fusek 2008; Rejholcová 1971). Poznáme ich napríklad z týchto lokalít: Spišské Tomášovce - Pod hradiskom, objekt 28 a 29 (Béreš/Šalkovský 1978, obr. 8), Prešov-Pod Bikošom (Tomášová 1990, 161), Sliač-Horné zeme (Mácelová 2013, 46, 48; Šalkovský 2011a, obr. 21), Detva-Kalamárka (Šalkovský 1994, 168, 169; 2011a, 48), Hurbanovo-Bohatá (Rejholcová 1977, 656, obr. 6-8). Z d’alších hodno spomenút keramický súbor z lokality Nitra-Šindolka (Fusek 2008, 25), Čeladice-Hanisovo (Ruttkayová/Ruttkay 2004, 328), Bajč-Medzi kanálmi (Ruttkay 2002, 273) a iné (Šalkovský 1994, 169; 2011a, 45-48).

\section{OSTATNÉ NÁLEZY}

Okrem početných zdobených črepov sa v čiernej výplni objektu našli štyri kusy pieskovcových brúsikov. Dva z nich boli nepravidelného tvaru, tretí mal pravidelný štvorcový prierez. Signifikantný je štvrtý brúsik sivobielej farby, pôvodne obdížnikovitého prierezu. Tým, že bol často požívaný, je jeho povrch z každej strany konvexne prežliabnutý (obr. 13: 1). Brúsne kamene boli bežnou výbavou a slúžili na brúsenie či už kovových alebo kostených častí pracovných nástrojov (Šalkovský 2011a, 67). O textilnom spracovaní svedčí nález dvojkónického hlineného praslena, vyrobeného z jemne plavenej hliny so stopami po ryhovaní v tvare slnečných lúčov na vrchnej a spodnej strane (obr. 13: 3; vonkajší pr. $31 \mathrm{~mm}$, pr. vnútorného otvoru $8 \mathrm{~mm}$, v. $14 \mathrm{~mm}$ ). Nálezy 


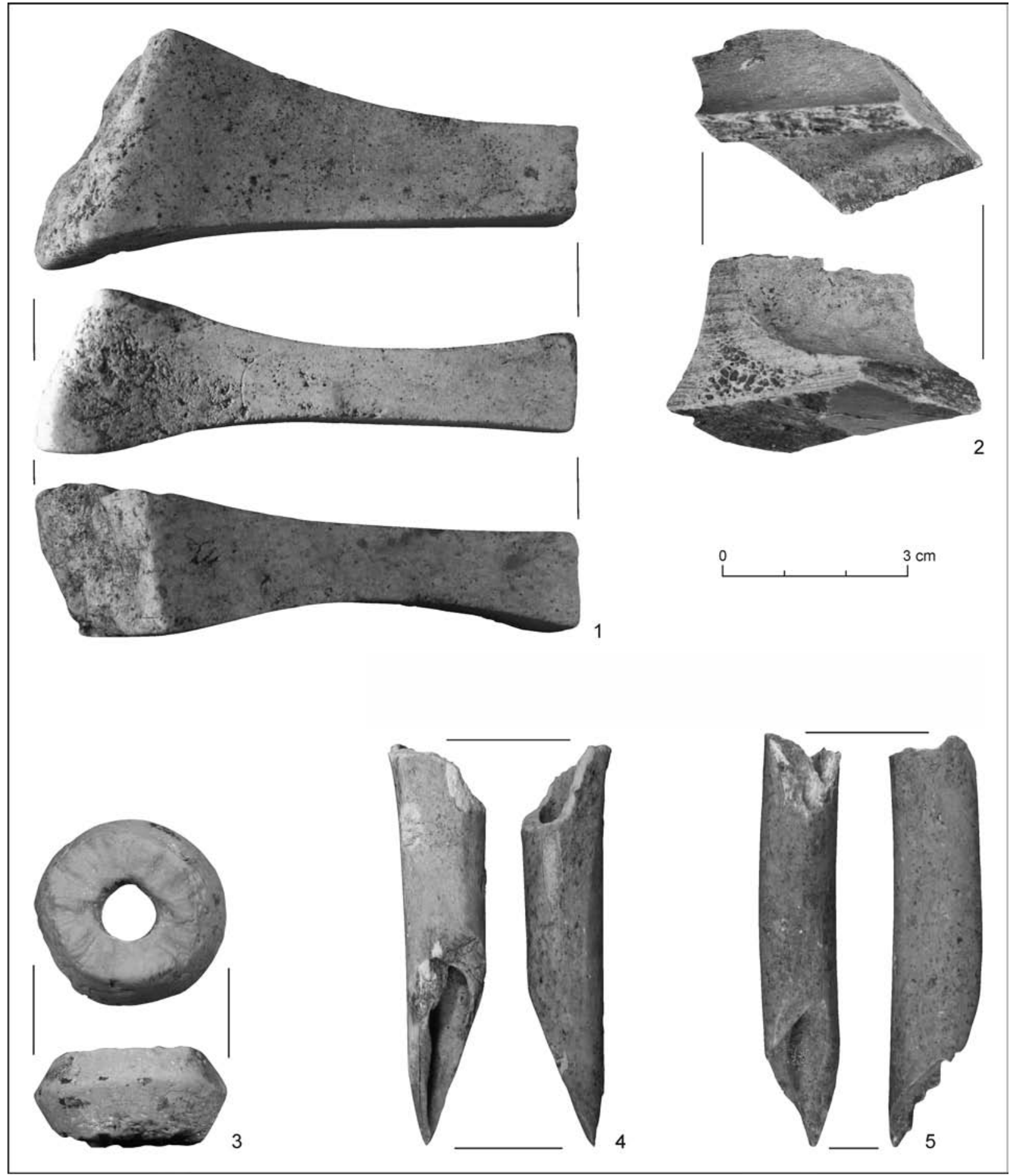

Obr. 13. Smižany, poloha OD TESCO, sonda III/11, obj. 1. Drobné nálezy. 1 - kamenná brúska; 2 - rezaním opracovaná kost’; 3 - hlinený praslen; 4, 5 - kostené šidlá. Foto P. Fecko.

praslenov z včasnostredovekého obdobia sú početné po celom Slovensku, no nie sú chronologicky citlivé (Fusek 1994a, 80; Ruttkayová/Ruttkay 2004, 325; Šalkovský 2011a, 66). Z kostenej industrie sa našli dva do hladka vyhladené zlomky šidiel (obr. 13: 4, 5), ktoré podobne ako prasleny svedčia o spracovaní odevu a rovnako sa vyskytujú v značných množstvách na sídliskách z daného obdobia (Odler 2014, 48, 49, obr. 22: e, g; Šalkovský 2011a, 68, 69). Na jednej zo zvieracích kostí je zretelné opracovanie rezaním (obr. 13: 2). 


\section{PREHL'AD VČASNOSTREDOVEKÉHO OSÍDLENIA V KATASTRI SMIŽIAN}

Horeuvedená zemnica z polohy TESCO iste patrí do sústavy slovanských sídlisk, ktoré pravdepodobne vytvárali hospodárske zázemie čingovských hradísk v Spišských Tomášovciach/Smižanoch. Z katastra Smižian evidujeme viaceré polohy datované do včasnostredovekého obdobia (obr. 1). Pri ich spracovaní sme nechceli vychádzat iba z dostupnej literatúry, ale prikročili sme k fyzickému prehodnoteniu dostupného keramického materiálu uloženého v depozitári AÚ SAV, pracoviska Spišská Nová Ves (dnes Oddelenie záchranných výskumov - Spiš). Na konci každej z polôh je stručná charakteristika týkajúca sa našich pozorovaní.

Najbližšie k polohe TESCO (1) je známa lokalita na Ulici kpt. J. Nálepku (2; dnes ulica Nálepkova). V roku 1977 pri budovaní kanalizácie vykonal F. Javorský prieskum rýh, v ktorých identifikoval kultúrne jamy. Okrem nálezov z 13. stor. spomína aj črepy podobné s nálezmi z polohy Pod hradiskom v Spišských Tomášovciach a rámcovo ich datuje do 10. stor. (Javorský 1978, 109). Revíziou sa nám podarilo získat iba jeden keramický fragment z tela nádoby, ktorý možno rámcovo zaradit do 11.-12. stor. Ide o zlomok s prímesou hrubozrnných kamienkov s výzdobou v tvare jednoduchej, širokej vlnovky.

Západne od obce evidujeme lokalitu Zlaté role (3), kde v roku 2004 uskutočnili povrchový zber E. Horváthová, R. Hreha a R. Rusnák. Našli nepočetne úlomky keramiky, ktoré iba rámcovo datujú do obdobia včasného stredoveku (Horváthová/Hreha/Rusnák 2006, 94). Nálezy z uvedeného prieskumu sme nemali k dispozícii, preto sa k nim nemožno bližšie vyjadrit.

Približne 500 m na severozápad od predošlej polohy sa nachádza lokalita Pri kňazovej studni (4). Počas rokov 1977, 1979 a 1982 tu uskutočňoval povrchové zbery F. Javorský. Nájdenú slovanskú keramiku datoval do chronologických období 8.-10., 9.-10. a 11.-12. stor. Z jeho správ sa dozvedáme, že na juhozápadnom okraji lokality, teda bližšie k potoku Brusník, došlo k narušeniu jedného velkomoravského objektu s ohniskom. Spomínaný autor tiež uviedol, že na celej ploche sa vyskytuje množstvo železnej trosky (Javorský 1978, 109; 1979; 1982; 1983, 108). Na základe hmotnosti črepov získaných zo zberu pochádza z tejto polohy najväčšie množstvo fragmentov. Keramické nálezy možno rámcovo datovat do 8.-10. stor.

Dôležitá poloha sa nachádza na lavobrežnej terase rieky Hornád, približne $500 \mathrm{~m}$ na juh od polohy TESCO. V literatúre sa na tomto mieste spomínajú dve polohy a to Štrkovisko II a IV. Keďže ide o lokality vzdialené od seba $400 \mathrm{~m}$, medzi ktorými sa nenachádza žiadna prírodná bariéra, spojili sme ich pod jednu polohu s názvom Štrkovisko IV (5). V západnej časti tohto priestoru, oproti železničnej stanici v Smižanoch (Štrkovisko II - obr. 1: 5b), bol v roku 1967 zistený slovanský kostrový hrob (Kovalčík/Badík 1968). V tom čase išlo o prvý nález hrobu z včasného stredoveku na území Spiša (Javorský 1993, 27). Bližšie nálezové okolnosti hrobového celku však nie sú isté. Nádobu s rozrušenou kostrou ${ }^{5}$ odovzdal do Vlastivedného múzea v Spišskej Novej Vsi T. Bartoš, ktorý pracoval ako šofér vtedajšieho JRD (Polnohospodárskeho družstva) pri tažbe a odvoze štrku. Podla opisu autorov ide o hrubostennú nádobu, nerovnomerne súdkovitého tvaru modelovanú v ruke s nevýrazným obtočením povrchu, so zaobleným a von vyhnutým okrajom. Výzdobu povrchu predstavuje dvojica obežných, nepravidelne sa prekrývajúcich vlnoviek s nepravidelným sklonom, pod ktorými sa nachádza obežná neuzavretá línia. Na dne je odtlačok pravdepodobne po oske hrnčiarskeho kruhu (Kovalčík/Badík 1968, 235). Nádobu poznáme $\mathrm{z}$ autopsie a podla našich pozorovaní bola vymodelovaná iba v ruke bez použitia hrnčiarskeho kruhu. Rovnako na dne nie sú žiadne stopy po oske. V literatúre sa d’alej uvádza, že vzhladom k parametrom (v. $10,3-10,9 \mathrm{~cm}$, pr. vonkajšieho ústia 11,1-11,3 cm, pr. najväčšej vydutiny tela $11,8 \mathrm{~cm}$, pr. hrdla 10,2 cm, pr. dna $9,3 \mathrm{~cm}$ ) ide o zriedkavý typ nádoby $\mathrm{v}$ danom regióne. Rozmerovo podobnú nádobu však poznáme zo susednej lokality Smižany - Hradisko II (v. 10,2 cm, pr. vonkajšieho ústia $10 \mathrm{~cm}$, pr. najväčšej vydutiny tela $11 \mathrm{~cm}$, pr. hrdla $9,3 \mathrm{~cm}$, pr. dna $8 \mathrm{~cm}$ ). Nádoba je uložená v depozitári Múzea Spiša, pobočka Smižany. ${ }^{6}$ Má však pravidelnejší tvar tela, rovnako pravidelnejší je aj nanesený dekór v podobe troch radoch jednoduchej vlnovky začínajúcej na hrdle nádoby. ${ }^{7}$ Obdobný exemplár pochádza z juhomoravskej lokality

5 Kostrový hrob autori príspevku definovali na základe troch častí ludských kostí: l'avá ramenná kost', pravá lícna kost a čast’ prvého stavca krížovej kosti (Kovalčík/Badík 1968, 235).

6 Nádoba pochádza zo zberu M. Vojtáša z roku 1955.

7 Na zrekonštruovanej nádobe je nesprávne interpretovaný dekór situovaný na hrdle v podobe nechtového vrypu. Ide o jednoduchú vlnovku s nepravidelnou vysokou amplitúdou. 
Šardičky primesteBučovice.Lokalitajeznámahlavnepohrebiskomunětickejkultúry (Procházka/Chleborád/ Kalousek 1927). Na jeho okraji sa našlo 11 slovanských hrobov datovaných do 9. stor. (Kuželová 2012, 46). Z hrobu 11 pochádza v ruke modelovaná nádoba s hrubými stenami zdobená jednoduchou, hrubo vyrytou vlnovkou, označená ako hrnček (Černohorský 1952, 224; Poulík 1948, 28, tab. LXX: 5; Procházka/Chleborád/Kalousek 1927, 32, 33, tab. I: 16). Z ostatných lokalít, s podobnou v ruke modelovanou keramikou na území Moravy, možno spomenút obec Blučina (okr. Brno) ${ }^{8}$ alebo Rousínov (okr. Vyškov). ${ }^{9}$ Datovanie nádoby zo spomenutého kostrového hrobu z polohy Štrkovisko II je vzhladom na absenciu iných hrobových príloh problematické. Rámcovo ju datujeme do 8.-10. stor. Aj ked' je nádoba modelovaná v ruke, nesvedčí to nič o jej staršom pôvode. Hlavne jej výzdoba v podobne širokej jednoduchej vlnovky a obežnej ryhy napodobňuje ornament nádob datovaných do 9.-10. stor. Na príklade kostrového pohrebiska v Blučine možno sledovał', že $\mathrm{v}$ dobe vyspelej na kruhu obtáčanej keramiky sa vyrábali tiež nádoby robené po domácky. V našom prípade nie je tiež vylúčené, že v dobe úmrtia nebožtíka nebolo možné zadovážit si nádobu zhotovenú na kruhu. Pozostalí tak boli nútení použit podomácky v ruke modelovanú nádobu, ako to opisuje napr. J. Poulík $(1948,30)$.

V liste V. Budinského-Kričku, adresovanému riaditel'stvu AÚ SAV Nitra, sa spomína táto poloha nesprávne ako Roveň. Ďalej sa v ňom uvádza, že sústavnejšiemu záchrannému výskumu na lokalite prekážajú vysoké haldy ornice, vytláčanej buldozérmi na okraj štrkoviska. Jediným východiskom podla neho bolo časté sledovanie lokality a zachraňovanie nálezov z poškodzovaných objektov (Budinský-Krička 1976). Ďalšie prieskumy polohy realizované F. Javorským sa uskutočnili až po takmer desiatich rokoch. V priebehu roku 1976 tu horeuvedený autor uskutočnil záchranný výskum neolitického domu. Okrem neolitických nálezov uvádza aj črepy z doby vel'komoravskej (Javorský 1977a, 142). Z roku 1977 spomína, že poloha už vtedy bola zničená zástavbou a neustálou tažbou štrku. Črepy získané prieskumom rámcovo datoval do 9. stor. (Javorský 1978, 110, 111). Nasledujúci rok 1978 sa situácia vôbec nezmenila. Opät sa spomína tažba štrku a ničenie objektov na polykultúrnej lokalite. Záchranným prieskumom sa získali nálezy z viacerých období (neolit, doba bronzová, mladšia/neskorá? doba rímska), pričom sa v menšom počte spomínajú aj vel'komoravské črepy (Javorský 1980, 128). Podla hmotnosti črepov získaných zo zberov je táto poloha na druhom mieste. Väčšina keramiky sa nedá bližšie datovat ako do rozmedzia 8.-10. stor. Za zmienku stoja informácie F. Javorského, podla ktorých sa počas jeho záchranných aktivít na ploche našli aj uzavreté nálezové celky patriace do obdobia včasného stredoveku. ${ }^{10} \mathrm{Z}$ roku 1976 (Štrkovisko III) uviedol objekt 1/76. Okrem črepov datovaných do 8.-10. stor. sa medzi nimi vyskytol aj okraj nádoby, v ruke robenej a s otáznym datovaním do 6.-7. stor. Počas revízie sme v ruke robené fragmenty keramiky identifikovali aj zo zberu v roku 1972, ktoré sa dajú rámcovo datovat do 7.-8. stor. Dvanást kusov nájdených črepov svojím vzhladom pripomína keramický súbor objavený v Spišskej Novej Vsi, poloha Pod Modrým vrchom, a to v uzavretých objektoch (91-93) z roku 2017, datovaných do 7. stor. Z roku 1977 (Štrkovisko IV) spomenul Javorský nálezy z výplne jamy, v ktorej spočívala tiež slovanská vrstva. Z ôsmych uvádzaných črepov však možno len tri pokladat za slovanské a datovat ich do 8. -10. stor. Podobne je to aj v prípade objektu 2/77. Z piatich črepov uvádzaných ako slovanské sú štyri nevýrazné a pripomínajú skôr keramiku z doby bronzovej. Jeden tenkostenný fragment okraja z jemne plavenej hliny, zdobený na pleci obežnou líniou, možno zaradit do 9.-10. stor. Do rovnakého obdobia radíme aj objekt 8/77, z ktorého pochádza devät črepov. Z nich dva okraje pripomínajú keramiku z doby bronzovej. Šest' zdobených črepov z jemne plavenej hliny je nepochybne mladších ako v prípade objektu 1 z polohy TESCO.

Západne od polohy Štrkovisko IV, na analogickej lavobrežnej terase rieky Hornád, je známa lokalita Smižianska Maša (6). V literatúre je pracovne rozdelená na Smižiansku Mašu I a II. Objavená bola v roku 1977, kedy tu povrchový prieskum uskutočnil F. Javorský. Okrem črepov z mladšej doby bronzovej sporadicky nachádzal aj slovanské črepy, ktoré rámcovo datoval do 8.-9. stor. (Javorský 1978, 109, 110). Záchranný výskum realizoval ten istý autor v roku 1983, kedy sledoval ryhy vykopané pre vodovodné potrubie. V ich profiloch identifikoval zničené sídliskové objekty, datované hlavne do mladšej doby

8 Z porušených hrobov na kostrovom pohrebisku v Blučine je nádobka, ktorá sa svojou výzdobou zhoduje s nádobami blučinského tvaru, ale spôsobom výroby sa od nich značne odlišuje. Keramika je modelovaná v ruke, povrch má nerovný a steny sú nerovnako hrubé (Poulík 1948, 28, obr. 10: 2).

9 Poulík 1948, 28, obr. 10: 1. Týmto by sme chceli upozornit na prehodené číslovanie nádob v horeuvedenej publikácii. Zatial čo číslovanie pod obrázkom 10 je správne, tak v texte je prehodené.

10 Väčšina týchto informácií pochádza z papierových vreciek, v ktorých boli nálezy uložené. Chýba však kresbová a fotografická dokumentácia. 
bronzovej a jeden do mladšej doby rímskej. V sídliskovej vrstve nad a vedla spomenutých objektov sa nachádzali aj črepy z vel'komoravského obdobia, ktoré zaradil do 9.-10. stor. (Javorský 1984, 101). Viaceré povrchové prieskumy uskutočnené F. Javorským sú nám d’alej známe z rokov 1985 a 1986, počas ktorých nachádzal slovanské črepy datované do rovnakého časového horizontu ako je spomenuté vyššie (Javorský 1985; 1986). Počas revízie sme identifikovali 21 črepov z danej polohy, ktoré sa dajú iba rámcovo zaradit do 8. -10. stor.

Ďalej na západ, popri lavom brehu rieky Hornád sa nachádza poloha Baniská. V roku 1977 tu F. Javorský uskutočnil povrchový prieskum, počas ktorého identifikoval v teréne akúsi spojovaciu cestu vedúcu k Hradisku I v Smižanoch/Spišských Tomášovciach. V jej okolí vo svahu kopca objavil milierové plošiny bez možnosti bližšieho časového zaradenia, kde sa v minulosti pálilo drevené uhlie (Javorský 1978, 110). Revízny povrchový prieskum v roku 2004 bol však negatívny na akékolvek nálezy (Horváthová/Hrehal Rusnák 2006, 94).

Na rozhraní katastrov Smižany a Spišské Tomášovce evidujeme lokalitu Gnojník (7). Podobne ako vyššie uvedené lokality, aj táto bola pracovne rozdelená ako Gnojník I a II. Aj napriek tomu, že obe polohy sú lokalizované na rozdielne situovaných svahoch a oddelené močaristým terénom, kde pramení bezmenný potok, ide pravdepodobne o jedno a to isté sídlisko. Nasvedčuje tomu i krátka vzdialenost medzi nimi, predstavujúca asi 100 metrov. Prvým zberom v roku 1977 sa získali okrem nálezov z doby bronzovej aj črepy datované do 9. stor. (Javorský 1978, 113). Ďalšie správy zo zberov sú známe až o dvadsat’ rokov neskôr, a to z roku 1997 od toho istého autora. Prieskumom sa získali črepy, ktoré datoval do 8.-10. stor. (Javorský 1997a). O rok neskôr M. Soják povrchovým prieskumom získal okrem iného tiež slovanské črepy datované do 9.-10. stor. (Soják 1998; 2000, 162; 2017, 69). Vzhladom k tomu, že všetky nálezy pochádzajú z prieskumu, aj túto polohu možno datovat len rámcovo do 8.-10. stor.

Východne od polohy Štrkovisko II (600-700 metrov) je evidovaná archeologická lokalita Smižianska roveň (8). Nachádza sa na rozhraní katastrov Smižany a Spišská Nová Ves. Počas výstavby sídliska Západ v roku 1984 sa zberom našli črepy datované do 9.-10. stor. (Javorský 1985, 117, 118). Ďalší prieskum sa uskutočnil v roku 1988 a podla správ F. Javorského sa dozvedáme, že slovanské osídlenie sa koncentruje hlavne vo východnom smere (Javorský 1990a, 75; Soják 2001, 182, 183). Počas revízie sme identifikovali 36 črepov, ktoré rámcovo datujeme do 8.-10. stor. Zaujímavý je fragment okraja získaný zo zberu F. Javorského v roku 1984. Ide o vrchnú čast’ v ruke modelovanej hrubostennej nádoby. Na vnútornej stene sú stopy prstov po vytahovaní hliny smerom nahor. Na základe horeuvedených vlastností a podobností s keramikou nájdenou na lokalite Spišský Štvrtok - Pod Šibeničnou horou rámcovo črep datujeme do 6. -7. stor.

Dvesto metrov severovýchodne od Hradiska I sa nachádza lokalita Sedlo pod hradiskom (9). V roku 1976 sa tam konal záchranný archeologický výskum, počas ktorého boli objavené kultúrne vrstvy z viacerých období, vrátane včasnostredovekého. Zaujímavý je nález zvyškov kostrového hrobu (2/76), ktorý však neobsahoval žiadny nálezový inventár, preto zostáva jeho datovanie problematické. Okrem toho sa našli črepy, ktoré F. Javorský zaradil do predvel'komoravského a vel'komoravského obdobia (Javorský 1977b, 154 n.). V súvislosti s výkopom ryhy pre uloženie telefónneho kábla v blízkosti hotela Čingov tu v roku 1998 robil záchranný výskum formou sledovania výkopových prác M. Soják. Medzi nálezovým materiálom z mladšej doby bronzovej a púchovskej kultúry staršej doby rímskej sa nenašli žiadne včasnostredoveké črepy (Soják 2000, 161, 162). Počas prieskumu predpolia Slovenského raja v roku 2004 boli podla autorov na oráčine viditelné tmavé škvrny, z okolia ktorých sa zozbierali črepy zdobené rytými obežnými líniami, železnú trosku a sklovitú pastu. Autori prieskumu datovali črepy rámcovo do včasného stredoveku (Horváthová/Hreha/Rusnák 2006, 94). Nálezy z uvedeného prieskumu sme nemali k dispozícií, preto sa nemôžeme k ním relevantnejšie vyjadrit'.

Poloha Čingov (12) označovaná aj názvom Pri starej horárni sa nachádza východne od Hradiska II a južne od Hradiska I. V roku 1983 získal F. Javorský povrchovým prieskumom 27 črepov, ktoré rámcovo datoval do 9.-10. stor. (Javorský 1984, 101). Revíziou sme zistili, že ide o 21 nevýrazných črepov pochádzajúcich z tiel nádob, dva okraje a štyri kusy zdobených črepov. Keramika pôsobí mladším dojmom ako $\mathrm{v}$ prípade nájdeného súboru z objektu $1 \mathrm{v}$ polohe TESCO. Je tenkostenná, vyrobená z jemne plavenej hliny, výzdoba v podobe viacnásobnej a jednoduchej vlnovky má širšie žliabkovanie. Preto sa prikláňame k rovnakému časovému zaradeniu ako uvádza F. Javorský.

Nad pravým brehom Hornádu, približne 1100 metrov juhozápadne od osady Smižianska Maša, sa nachádza jaskyňa Tri skalky (13). Ide o polykultúrne nálezisko, kde sa okrem nálezov z iných období spomínajú aj pamiatky z 9.-11. stor. Jaskyňu amatérsky „skúmal“ M. Macalík zo Smižian v rokoch 
1992 a 1994. F. Javorský na základe nálezov zo spomínaných výskumov nevylučuje dlhodobejšie osídlenie jaskyne aj v dobe vel'komoravskej (Javorský 1997b, 100 n.). Väčšina nájdených črepov nám nie je známa a pravdepodobne skončila v súkromnej zbierke M. Macalíka. K dispozícii je len niekol'ko málo črepov rámcovo zaradených do 10.-12. stor. (Soják 2007, 59 n., obr. 59: 1-6). Jeden z okrajových fragmentov najmä s horizontálnym rebrovaním na hrdle hrncovitej nádoby nápadne pripomína keramiku zo zahĺbeného objektu z Letanoviec, polohy Olmár a zaradeného do 10.-11. stor. (Soják 2005, obr. 13: 1).

Skúmanie slovanských hradísk v katastroch obcí Spišské Tomášovce/Smižany viedlo F. Javorského k tomu, aby začal sledovat aj komunikácie spájajúce vel'komoravské i povel'komoravské osady s inými regiónmi. Podla jeho prieskumov sa dozvedáme, že najvhodnejšia cesta s južnými gemerskými oblastami mohla viest’ od Hradiska II hrebeňom vrchu Matky Božej (14) až k Mlynkom - Palcmanskej Maši, alebo dolinou potoka Lesnica s tým istým vyústením. Ako druhú alternatívu pripúšta, že cesta mohla viest’ tiež cez lokalitu Turník (15). Ide o polohu nachádzajúcu sa na polane medzi Predným a Zadným Turníkom (Javorský 1977a, 143, 144). V roku 1976 na tomto mieste urobil F. Javorský zistovaciu sondu. Po revízii nálezov v depozitári v Spišskej Novej Vsi sme však nálezy zo spomínaného prieskumu nenašli a nemohli sme ich overit. František Javorský vo svojom príspevku z roku 1977 (Javorský 1977a, 144) na základe získaných nálezov ohraničil osídlenie lokality do obdobia od 10. do 15. stor. O rok neskôr vykopal spomínaný autor opät zistovaciu sondu. Medzi najstaršie nálezy však patrili črepy datované už do druhej polovice 13. stor. a neskôr (Javorský 1978, 111).

Južne od slovanských hradísk sa nachádza dominantný kopec s už spomenutým názvom Matka Božia (14). Informáciu, že ide o slovanské kultové miesto spomínané v literatúre však nemáme čím potvrdit ani vyvrátit. F. Javorský pri svojich tvrdeniach vychádzal z toponyma daného miesta, ako aj z terénnych prieskumov polohy. Spomínaný bádatel’ uvádza, že na vrchole kopca sa nachádza kamenný materiál sústredený v prstencovitom útvare o priemere asi 12 až $15 \mathrm{~m}$, okolo ktorého sa tiahne kamenný val alebo múrik (Javorský 1978, 111). Tieto tvrdenia je však potrebne dokázat’ realizáciou sondážneho archeologického výskumu na danom mieste.

Z analýzy nálezov vidiet', že väčšina pochádza iba z povrchových prieskumov. Ide o jednu z najdôležitejších výskumných metód v rámci mikroregiónu a súvisiacu so získavaním informácií o osídlení. Takto získaný materiál má však rozhodne svoje negatíva, ktoré neposkytujú rovnakú kvalitu informácií z hladiska chronologického a priestorového, na rozdiel od artefaktov získaných z uzavretých nálezových celkov. Pri analýze archeologických polôh v rámci katastra sme sa snažili vyhnút zbytočnému prehusteniu, ktoré vzniká už v priebehu povrchového prieskumu rozdelením polohy na viacero sektorov. ${ }^{11} \mathrm{~V}$ prípade kartografického spracovania tak môže vzniknút dojem, že v istej oblasti je nápadne hustá koncentrácia sídlisk. Vychádzali sme z rozpracovanej tézy o nutnom areáli potrebnom pre vyplnenie základných hospodárskych potrieb sídliska, ktorú rozpracoval pre neolitické a eneolitické kultúry P. Milo a kolektív (Milo et al. 2004, 132). Vo svojej práci uvádzajú priemernú vzdialenost' medzi sídliskami $1,12 \mathrm{~km}$. Podla ich predpokladu na jednom sídlisku mohlo v jednej fáze osídlenia stát 4 až 6 domov. Na jeden dom odhadujú šest’ obyvatelov. Vel'kost’ jedného takéhoto sídelného areálu zodpovedá kruhu s polomerom cca $0,5 \pm 0,1 \mathrm{~km}$. Ich zistenia o počte domov a obyvatelov v rámci jednej osady tak korešpondujú s poznatkami o včasnoslovanských sídliskách (porovnaj napr. BeranoválLutovský 2009, 22; Jelínková 1980, 425; Pleinerová 1975, 27, 49).

\section{DATOVANIE A ZÁVER}

Pravdepodobne všetky včasnostredoveké lokality v okolí hradísk na Čingove zohrávali dôležitú úlohu v zázemí významných lokalít v polohách Hradisko I a II (10, 11). Na tomto mieste sa nechceme venovat' ich histórii výskumu, nájdenými pamiatkami či architektúrou hradieb. Súhrn literatúry o spomenutých hradiskách najnovšie zhrnul v monografii o Spišských Tomášovciach M. Soják (2017, 62-69). Je len na škodu bádania, že archeologické výskumy realizované v minulosti neboli doteraz komplexne spracované. Najnovšie správy pochádzajú z roku 2006 od kolektívu autorov (Staššíková-Štukovská a i. 2006), ktoré majú iba informatívny charakter. Nakol'ko doteraz bol zverejnený iba výber nálezov staršieho a mladšieho charakteru (Bérě̌/Šalkovský 1978, 37; obr. 6, 8; Béreš/Štukovská 1980, 44; obr. 18 a iné), nemožno keramiku z hradísk v Smižanoch/Spišských Tomášovciach použit pri

\footnotetext{
11 Porovnaj napríklad polohy ako Gnojník I a II alebo Štrkovisko I, III, IV či Smižianska Maša I a II.
} 
porovnávacom štúdiu. Podobný problém je napríklad pozorovatelný aj na pobedimskom hradisku (Fusek 2008, 32; 2013, 147).

Väčšinu keramického materiálu pochádzajúceho z prieskumov rámcovo datujeme do 8. až 10. stor. Jediným vhodným prostriedkom $\mathrm{k}$ datovaniu objektu $1 \mathrm{v}$ polohe TESCO je $\mathrm{v}$ ňom nájdený keramický súbor. ${ }^{12}$ Ten ako celok, ktorý má určité charakteristické znaky, sme porovnávali s náplňou jednotlivých starších alebo mladších horizontov včasnostredovekých uzavretých celkov na Spiši. Zo staršieho horizontu možno spomenút napríklad lokalitu z konca 6. a začiatku 7. stor. v Spišskom Štvrtku, poloha Pod Šibeničnou horou, alebo Iliašovce-Za Hostincom. V roku 2016-2017 sa podarilo v Spišskej Novej Vsi, v polohe Pod Modrým vrchom, odkryt' zatial' nepublikované sídliskové objekty datované do 7. stor., ktoré obsahovali keramiku robenú v ruke. Na lokalite Spišský Štvrtok-Široké III boli počas záchranného výskumu na stavenisku dial'kového vodovodu v roku 1988 preskúmané časti zahĺbených príbytkov zničených pri odhumusovaní. V nepoškodených častiach dvoch objektov F. Javorský údajne zistil upravené dlážky a ohniská. Keramiku z nich datoval do 8.-10. stor. (Javorský 1990b, 87). Po fyzickom prehodnotení črepov, medzi ktorými sa nachádza v ruke robená keramika spolu s obtáčanou sa zistilo, že nájdený keramický súbor možno datovat' včaššie, do 7.-8. stor. ${ }^{13} \mathrm{~V}$ prípade keramiky z mladšieho horizontu (9.-10. stor.) sme zasa vychádzali napríklad z porovnania keramického súboru z objektu 17/80 v Spišskej Novej Vsi (Javorský 1981, 111). V roku 1980 sa začala na námestí rekonštrukcia kanalizácie medzi budovou MsNV a sochou kpt. Jána Nálepku, dnes na Zimnej ulici. Záchranným výskumom sa podarilo zachránit vyššie spomenutý objekt. Ide o zemnicu, ktorá mala v severozápadnej časti odstupňované zárezy, naznačujúce miesto vchodu. Pri západnej stene sa doložilo otvorené ohnisko. Nad úrovňou dlážky a pri stenách zahíbenia sa našli črepy z hrncovitých nádob, mazanica, zvieracie kosti, kamenný brúsik, hlinený praslen a železný nožík (Javorský 1981, 111, obr. 52: 3-6). Prikláňame sa k datovaniu autorov štúdie, ktorí slovanský objekt rámcovo zaradili do 9.-10. stor. (ČaplovičlJavorský 1990, 75, 87). Na Spiši je táto mladšia keramika technologicky vyspelejšia. Nádoby sú lepšie obtočené s výraznejšou profiláciou okrajov. Povrch je na dotyk jemnejší. Vo výzdobe sa uplatňuje nástup horizontálnych žliabkov, prechádzajúcich miestami do nízkych vlnoviek, ktoré sa niekedy prelínajú. Výzdoba, či už vlnoviek alebo horizontálnych línií, je redšia a robená širším jednohrotým nástrojom.

Svojím charakterom nesie keramický súbor z objektu $1 \mathrm{v}$ polohe TESCO znaky keramiky relatívne datovanej v slovenskej odbornej literatúre do 8. až 9. stor. (d’alší súpis sídlisk s analógiami pozri Fusek 2008, 28, 33, 34; Hanuliak 2016, 121, 122). Spodnú hranicu ohraničuje absencia v ruke modelovanej keramiky, ktorá posúva chronologické určenie približne do druhej polovici 8. stor. (Marková/Elschek 2002, 219; Fusek 2008, 30, 33; 2013, 146). Rovnako aj vo výzdobe sa rozpoznalo dožívanie starších tradícií, ktorá je zastúpená ornamentom $\mathrm{v}$ podobe krátkych zvislých či šikmých hrebeňovitých vpichov, alebo zárezov, vkomponovaných pod hrdlo alebo na pleciach (obr. 8: 2; 9: 3; 10: 1, 11, 14). Obluba tohto dekorovania na západnom Slovensku je podla G. Fuseka $(2008,32)$ typická pre 8. a 9. stor.

Dôležité zastúpenie majú nádoby s ústiami zvnútra zdobenými vlnovkou (obr. 8: 3; 9: 3). Obšírnejšie sa tejto tematike venoval L. Galuška (1987, tu dalšia početná lit.). Ide o archaický dekoračný prvok, ktorý sa na keramike objavuje niekedy v polovici 7. stor. ${ }^{14}$, ale najväčší výskyt bol zaznamenaný v nasledujúcom 8. stor. s postupným vyznievaním v 9. stor. (Fusek 1994a, 63, 64; 2008, 32, 33; Galuška 1987, 78, 79; Rejholcová 1977, 654; Šalkovský 2011a, 45, 48). Najbližšiu analógiu zo Spiša poznáme napríklad z lokality Spišské Tomášovce-Pod hradiskom z objektu 137 (Béreš/Štukovská 1980, obr. 18: 4), resp. z tej istej lokality z objektu 28/76 $6^{15}$ (Javorský 1977b, obr. 98: 1). Na Slovensku sa vyskytujú porovnatelné paralely na lokalitách Sliač-Horné zeme (Mácelová 2013, 40, 46; Šalkovský 2011, 48), Čeladice-Hanisovo (Ruttkayová/Ruttkay 2004, 323), Nitra-Šindolka (Fusek 2008, 32), Hurbanovo-Bohatá (Rejholcová 1977, obr. 6: 4-7; 7: 1, 3, 8; 8: 4, 5, 7) a na mnohých iných (porovnaj Béreš 1985, 32; Mácelová 2013, 47; Odler 2014, 42, 43; Odler/Zábojník 2011, 146, 147; Rejholcová 1971, obr. 11: 5; 1977, 654; Točík 1963, 163, 164). Vel'ké zastúpenie nádob s takto zdobenou vnútornou stranou ústia nachádzame na včasnostredovekom pohrebisku v Želovciach (Čilinská 1973). Podla L. Galušku $(1987,78)$ sa nedajú vyčlenił konkrétne regióny, kde by

12 Datovanie iba prostredníctvom typologickej analýzy keramiky nie je ničím výnimočným. Bližšie pozri Fusek 1994a; 1994b; 2008, 21, 28; 2009, 99; 2013, 141; Hanuliak 2016, 114, 155; Šalkovský 1994, 165; 1997, 214.

13 Na v ruke robenú keramiku nás upozornil G. Fusek počas jeho pobytu v Spišskej Novej Vsi, za čo mu d’akujeme.

14 Na lokalite Sliač - Horné zeme sa v objekte 5/79 zistila keramika s týmto druhom výzdoby spolu s črepmi modelovanými v rukách (Mácelová 2013, 46).

15 Z objektu 28/76 pochádza tiež náušnica s dvoma uzlíčkami a hrozienkovým príveskom i jazykovité bronzové liate kovanie s esovitým rastlinným ornamentom (Javorský 1977b, 164). 

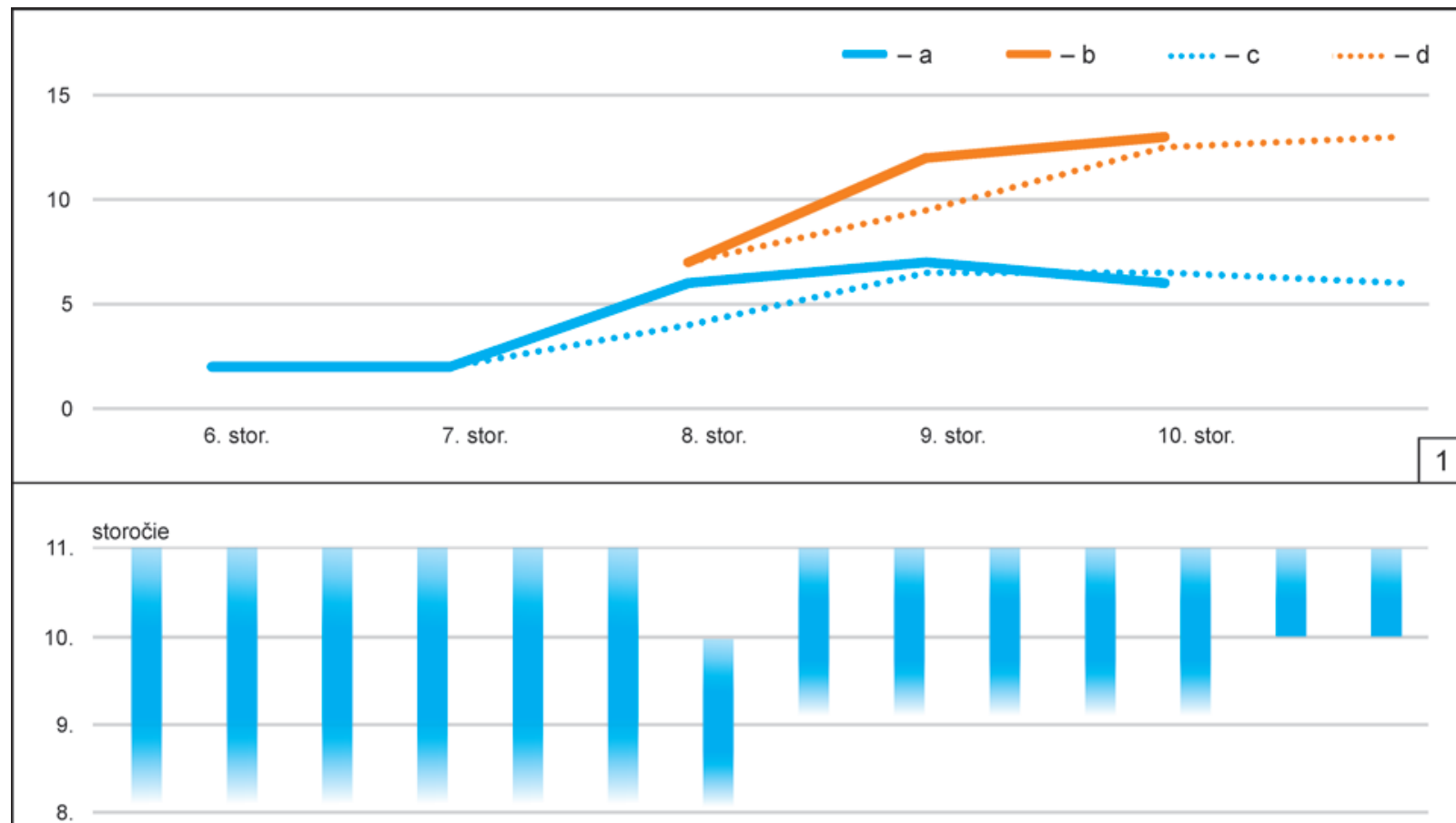

7.

6.
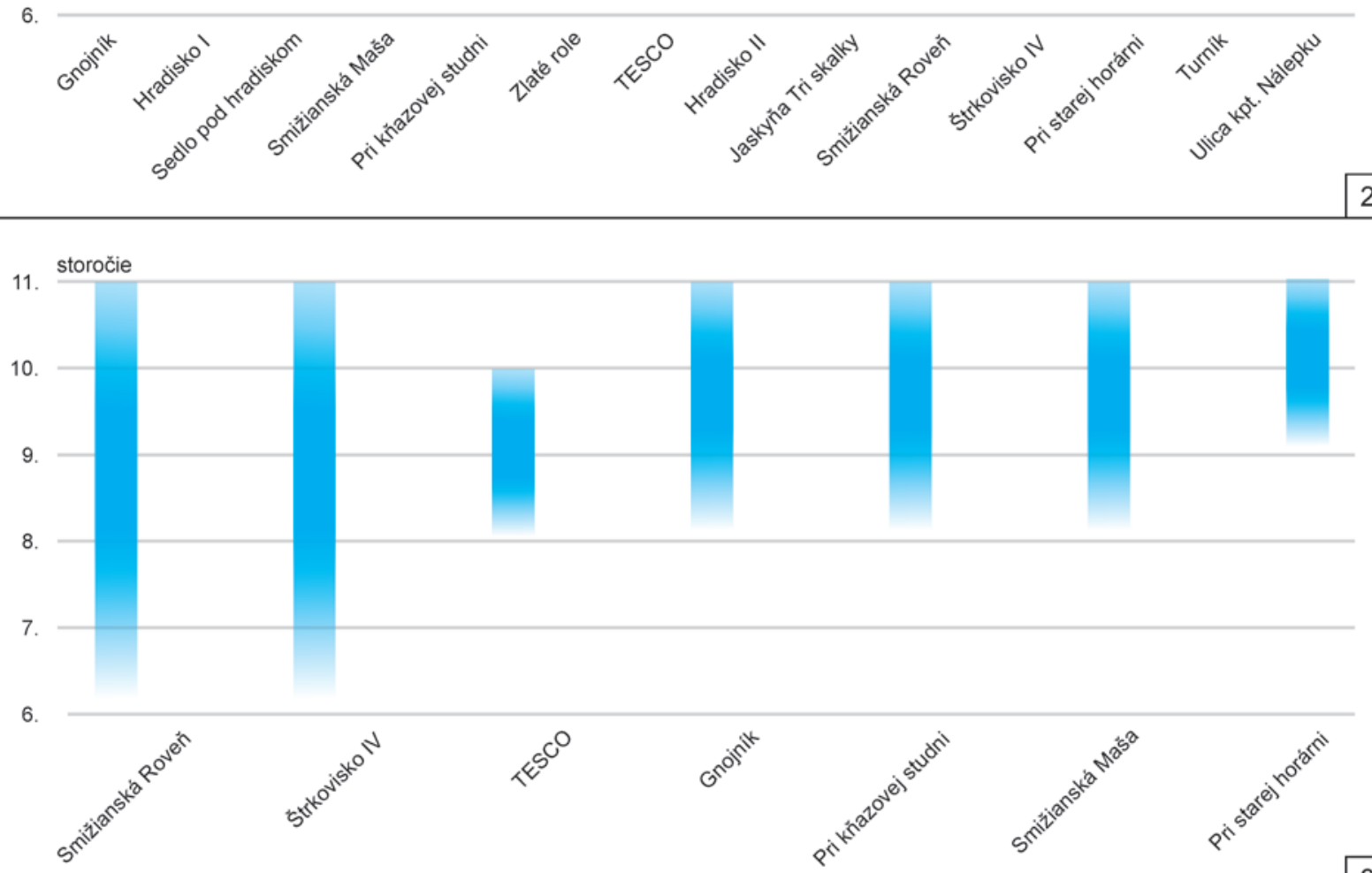

Obr. 14. Smižany, analýza datovania včasného stredoveku (6.-10. stor.). 1 - porovnanie datovania lokalít v katastri obce podla literatúry a na základe fyzického prehodnotenia keramiky; 2 - dynamika osídlenia v katastri vypracovaná na základe datovania uvedeného v literatúre; 3 - dynamika osídlenia v katastri vypracovaná na základe fyzického prehodnotenia keramického materiálu. Legenda: a - počet lokalít z daného storočia určených po prehodnotení keramiky; b - počet lokalít z daného storočia určených na základe literatúry; c - kĺzavý priemer chronologickej krivky určenej na základe prehodnotenia keramiky; d - kĺzavý priemer chronologickej krivky určenej na základe literatúry. 
tento druh dekorovania prevládal. Podla jeho prieskumu sa zdá, že najviac sa objavujú v južných oblastiach Slovenska a na východe.

Charakteristické pre zmienené obdobie 8. stor. je aj pozvolný nástup nového spôsobu výzdoby jednohrotým nástrojom (Fusek 2008, 25,33). Z objektu 1 však množstvo fragmentov s takouto výzdobou nebolo až také početné (obr. $7: 2 ; 10: 3 ; 11: 3)$.

Dna nádob a ich rôzne typy nie sú vhodným datovacím prostriedkom (Fusek 1991, 306). Odtlačky po oske hrnčiarskeho kruhu, aké sa našli v objekte $1 \mathrm{v}$ Smižanoch, však nachádzame aj na iných lokalitách datovaných do obdobia 8.-9. stor. ${ }^{16}$ Tento technologický prvok je podla G. Fuseka $(2008,33)$ najrozšírenejší na keramike stredodunajskej kultúrnej tradície v staršom úseku včasného stredoveku.

Pri chronologickom zaradení smižianskej zemnice do 8.-9. stor. možno vychádzat’ okrem keramiky aj z typov obydlia. Z literatúry je známe (Šalkovský 1983, 120; 2011a, 21), že dominancia domov tohto typu sa vyskytovala práve v 7.-8. stor. Na Slovensku prežíva tento druh objektov (typ 3) i v d’alších storočiach, hlavne na severovýchodnom a strednom Slovensku (Šalkovský 1998, 14).

Ani jeden z uvedených prvkov nie je vhodným datovacím kritériom (Fusek 1994a, 64, 65), ale ich zvýšený výskyt prevažuje práve v období od 8., resp. druhej polovice 8. do prvej polovice 9. stor., ako to definoval G. Fusek (2008; 2013, 146 n.).

Ako je uvedené vyššie, väčšinu nálezov tvoria črepy nájdené počas povrchových prieskumov, a preto sa nedajú bližšie datovat'. Aj preto má objekt 1 v polohe TESCO vel'ký význam z hladiska chronológie včasného stredoveku v regióne Spiša, ked’že ide o uzavretý nálezový celok. Hlavným prínosom pre poznanie včasnostredovekého osídlenia v katastri obce Smižany bolo priame prehodnotenie keramického materiálu, uloženého v depozitári AÚ SAV v Spišskej Novej Vsi. Dôležité je rozpoznanie fragmentov keramiky, ktoré posúvajú osídlenie pravdepodobne už od druhej polovice 6. stor. Komparatívna analýza datovania (obr. 14) na základe údajov z literatúry a potom podla priameho skúmania keramického materiálu priniesla nové poznanie o osídlení katastra v období včasného stredoveku. Na základe kartografického spracovania vidno, že osídlenie sa sústreduje hlavne v klimaticky priaznivejšej oblasti Hornádskej kotliny v okolí potoka Brusník, hlavne na jeho lavých brehoch a na lavej terase rieky Hornád, v nadmorskej výške od 460 do $550 \mathrm{~m}$. Vo väčšine prípadov sú osídlené miesta, kde prevláda práve v tejto oblasti najúrodnejší typ pôdneho predstavitela, čiernica.

Našou ambíciou v predloženom príspevku nebolo riešit relatívnu chronológiu včasného stredoveku na Spiši. Chceli sme však poukázat na význam uzavretých nálezových celkov, pri spracovaní ktorých je keramický materiál jediným prostriedkom pre chronologické určenie. To vychádza hlavne z porovnania náplne s inými horizontmi, v ktorých keramika ako celok má určité znaky, ktoré ju charakterizujú. Zároveň sme chceli poukázat' tiež na skutočnost', aké je dôležité (ak je to možné) pracovat’ okrem literatúry fyzicky s hmotnými prameňmi, v našom prípade s keramikou. Poznatky o jej typologickej náplni sa v priebehu času menia, a preto je dôležité ju opätovne prehodnocovat'.

\section{LITERATÚRA A PRAMENE}

Atlas 2001

Beranová/Lutovský 2009

Béreš 1985

Béreš 1995

Béreš/Odler 2011

Béreš/Šalkovský 1978

Béreš/Štukovská 1980

Budinský-Krička 1976

Budinský-Krička 1982
Atlas krajiny Slovenskej republiky. Banská Bystrica 2002.

M. Beranová/M. Lutovský: Slované v Čechách. Archeologie 6.-12. století. Praha 2009. J. Béreš: Keramika na tzv. avarských pohrebiskách a sídliskách zo 7.-8. stor. na Slovensku. Slovenská archeológia 33, 1985, 15-70.

J. Béreš: Slovanské pohrebisko v Dolnom Petre IV (teraz Svätý Peter). Slovenská archeológia 43, 1995, 111-160.

J. Béreš/M. Odler: Včasnostredoveké sídlisko Kubáňovo II. Študijné zvesti Aú SAV 50, 2011, 5-46.

J. Béreš/P. Šalkovský: Výskum slovanského hradiska v Spišských Tomášovciach. AVANS 1977, 1978, 36-38.

J. Béreš/D. Štukovská: Výskum slovanského hradiska v Spišských Tomášovciach. AVANS 1978, 1980, 42-46.

V. Budinský-Krička: List adresovaný Riaditel'stou AÚ SAV Nitra - Hrad pod číslom 212/76. Dokumentácia AÚ SAV v Nitre. Nitra 1976. Nepublikované.

V. Budinský-Krička: Nové nálezy na východnom Slovensku. AVANS 1981, 1982, 44-57.

\footnotetext{
16 Sliač, poloha Horné zeme (Mácelová 2013, 47, obr. 43: 8).
} 
Budinský-Krička 1990

Čaplovič/Javorský 1990

Černohorský 1952

Čilinská 1966

Čilinská 1973

Fecko 2016

Fecko a i., v tlači

Fusek 1991

Fusek 1994a

Fusek $1994 b$

Fusek 2008

Fusek 2009

Fusek 2013

Galuška 1987

Hanuliak 2015

Hanuliak 2016

Hanuliak/Vladár 2008

Horváthová/Hreha/Rusnák 2006

Javorský 1977a

Javorský 1977b

Javorský 1978

Javorský 1979

Javorský 1980

Javorský 1981

Javorský 1982

Javorský 1983

Javorský 1984

Javorský 1985

Javorský 1986

Javorský 1990a

Javorský $1990 b$
V. Budinský-Krička: Novyje materialy dla izučenija drevneslavianskoj keramiki na poselenijach Vostočnoj Slovakii. Slovenská archeológia 38, 1990, 89-146.

D. Čaplovič/F. Javorský: Najnovšie poznatky o vývoji stredovekého dedinského domu na Spiši. Nové Obzory 31, 1990, 69-122.

K. Černohorský: Keramika a feudalismus. Diskuse k studii akademika Jaroslava Böhma. K otázce o vzniku feudalismu v českých zemích. Český lid 9-10, roč. 39, 1952, 223-230.

Z. Čilinská: Slawisch - awarisches Gräberfeld in Nové Zámky. Bratislava 1966.

Z. Čilinská: Frühmittelalterliches Gräberfeld in Želovce. Bratislava 1973.

P. Fecko: Vymedzenie horskej oblasti Slovenska a jeho význam pre archeologické bádanie. Študijné zvesti AÚ SAV 59, 2016, 25-64.

P. Fecko/M. Kučerová/A. Kušnierová/M. Soják: Prvé včasnoslovanské nálezy zo Spiša. In: H. Útján 25, v tlači.

G. Fusek: Včasnoslovanské sídlisko v Nitre na Mikovom Dvore. Slovenská archeológia 39, 1991, 289-330.

G. Fusek: Slovensko vo včasnoslovanskom období. Nitra 1994.

G. Fusek: Analyse der Formen des handgemachten Keramikgeschirrs als Beitrag zur relativen Chronologie. In: Č. Staňa (Hrsg.): Slawische Keramik in Mitteleuropa vom 8. bis zum 11. Jahrhundert. Internationale Tagungen Mikulčice I. Brno 1994, $19-27$.

G. Fusek: Keramika predvel'komoravského horizontu z Nitry-Šindolky a otázka jej datovania. In: M. Guštin (Hrsg.): Srednji vek. Ljubljana 2008, 21-34.

G. Fusek: Odtlačky na dnách nádob v Nitre-Šindolke. In: P. Dresler/Z. Měřínský (ed.): Archeologie doby hradištní v České a Slovenské republice. Archaeologica mediaevalia. Moravica et Silesiana. Supplementum 2. Brno 2009, 99-108.

G. Fusek: Beitrag zu Problemen der Datierung von der Besiedlung der Westslowakei in der älteren Phase des Frühmittelalters. In: M. Dulinicz/S. Moździoch (ed.): The early Slavic settlement in Central Europe in the light of new dating evidence. Wrocław 2013, 139-150.

L. Galuška: K výzdobě vnitřních stran okrajů slovanských nádob. Časopis moravského múza Brno. Vědy spoločenské 72, 1987, 75-87.

M. Hanuliak: Včasnostredoveké osídlenie v Beckove. Slovenská archeológia 63, 2015, 115-149.

M. Hanuliak: Sídliská z 8.-10. stor. v Chl’abe. Slovenská archeológia 64, 2016, 95-143. M. Hanuliak/J. Vladár: Vel’komoravské sídlisko z Branča. Slovenská archeológia 56, 2008, 81-102.

E. Horváthová/R. Hreha/R. Rusnák: Prieskum predpolia Slovenského raja. AVANS 2004, 2006, 93, 94.

F. Javorský: Výsledky archeologického prieskumu v okrese Spišská Nová Ves. AVANS 1976, 1977, 138-152.

F. Javorský: Výsledky archeologického výskumu v Slovenskom raji. AVANS 1976, 1977, 153-166.

F. Javorský: Výskumy a prieskumy výskumnej expedície v okrese Spišská Nová Ves. AVANS 1977, 1978, 103-120.

F. Javorský: Smižany - Pri Kňazovej studni. Správa z povrchového prieskumu. Výskumná správa 8877/79. Dokumentácia AÚ SAV. Nitra 1979. Nepublikované.

F. Javorský: Výskumy a prieskumy Výskumnej expedície Archeologického ústavu SAV na Spiši. AVANS 1978, 1980, 123-131.

F. Javorský: Výskumy a prieskumy Výskumnej expedície Spiš Archeologického ústavu SAV. AVANS 1980, 1981, 108-126.

F. Javorský: Správa z povrchového prieskumu. Dokumentácia AÚ SAV. Spišská Nová Ves 1982. Nepublikované.

F. Javorský: Výskumy a prieskumy výskumnej expedície Spiš Archeologického ústavu SAV. AVANS 1982, 1983, 99-124.

F. Javorský: Záchranné výskumy a prieskumy výskumnej expedície Spiš. AVANS 1983, 1984, 96-112.

F. Javorský: Záchranné výskumy a prieskumy výskumnej expedície Spiš. AVANS 1984, 1985, 110-125.

F. Javorský: Smižany-Smižianska Maša II. Dokumentácia AÚ SAV. Spišská Nová Ves 1986. Nepublikované.

F. Javorský: Prieskum v okresoch Poprad, Spišská Nová Ves, Stará Lubovňa. AVANS 1988, 1990, 72 -80.

F. Javorský: Záchranné výskumy na stavbách, melioráciách a pri opravách sakrálnych objektov. AVANS 1988, 1990, 84-89. 
Javorský 1993

Javorský $1997 a$

Javorský $1997 b$

Jelínková 1980

Kovalčík/Badík 1968

Kučerová a i. 2012

Kuželová 2012

Mácelová 2013

Marková/Elschek 2002

Milo et al. 2004

Nevizánsky 1991

Odler 2014

Odler/Kolník 2011

Odler/Zábojník 2011

Pleinerová 1975

Poulík 1948

Procházka/Chleborád/Kalousek 1927

Rejholcová 1971

Rejholcová 1977

Ruttkay 2002

Ruttkayová 1991

Ruttkayová/Ruttkay 2004

Soják 1998

Soják 2000

Soják 2001

Soják 2005

Soják 2007

Soják 2017

Soják/Fecko 2011

Staššíková-Štukovská a i. 2006
F. Javorský: Z nepísaných dejín Smižian. In: F. Žifčák (ed.): Smižany. Smižany 1993, 14-29.

F. Javorský: Smižany. Správa z povrchového prieskumu. Výskumná správa 104/1997. Dokumentácia AÚ SAV. Nitra 1997. Nepublikované

F. Javorský: Osídlená jaskyňa v polohe Tri skalky pri Smižanoch. AVANS 1995, 1997, 100-101.

D. Jelínková: Obytné objekty s keramikou pražského typu z Mušova. Archeologické rozhledy 32, 1980, 413-434.

R. M. Kovalčík/M. Badík: Nález slovanského hrobu z doby hradištnej na Spiši. Vlastivedný zborník Spiš 2, 1968, 235-238.

M. Kučerová/M. Soják/A. Kušnierová/P. Fecko: Prvé včasnoslovanské nálezy zo Spiša. In: F. Fetko/M. Števík (zost.): Pocta Ivanovi Chalupeckému. Zborník príspevkov $k$ slovenským dejinám, vydaný pri príležitosti osemdesiatin doc. PhDr. Ivana Chalupeckého. Levoča 2012, 19-31.

P. Kuželová: Orientace hrobů vi̊či světovým stranám v 9. až 11. století na Moravě. Diplomová práce (Masarykova univerzita. Př́rodovědecká fakulta, Ústav antropologie). Brno 2012.

M. Mácelová: Slovania vo Zvolenskej kotline. Kraków 2013.

K. Marková/K. Elschek: Keramika z dendrochronologicky datovanej studne v Malackách. Študijné zvesti Aú SAV 35, 2002, 213-220.

P. Milo/R. Mlatec/F. Žák Matyasowszky/M. Žemla: Rekonštrukcia krajiny a osídlenia horného Požitavia v neolite a staršom eneolite. In: Acta archaeologica Opaviensia 1. 21. pracovní setkání. Otázky neolitu a eneolitu naších zemí. Opava 2004, $127-151$.

G. Nevizánsky: Kostrové pohrebisko z doby avarskej ríše vo Vyškovciach nad Iplom. In: K problematike osídlenia stredodunajskej oblasti vo včasnom stredoveku. Nitra 1991, 103-165.

M. Odler: Včasnostredoveké sídlisko Ivančiná-Kratiny (okres Turčianske Teplice). Zborník SNM. Kmetianum 13, 2014, 18-60.

M. Odler/T. Kolník: Včasnostredoveké sídlisko Cífer-Pác. Študijné zvesti AÚ SAV 50, 2011, 47-100.

M. Odler/J. Zábojník: Sídliska z 8. storočia na juhozápadnom. Slovensku Šal’a III, Úlany nad Žitavou, Pavlová. Študijné zvesti AÚ SAV 50, 2011, 101-220.

I. Pleinerová: Březno. Vesnice proních Slovanů v severozápadních Čechách. Praha 1975.

J. Poulík: Staroslovanská Morava. Praha 1948.

A. Procházka/M. Chleborád/F. Kalousek: Předvěká pohřebiště v Šardičkách u Bučovic. Brno 1927.

M. Rejholcová: Slovanské osídlenie stredoslovenského kraja. Slovenská archeológia 19, 1971, 96-133.

M. Rejholcová: Slovanské sídliskové objekty v Hurbanove-Bohatej. Archeologické rozhledy 29, 1977, 646-657.

M. Ruttkay: Mittelalterliche Siedlung und Gräberfeld in Bajč - Medzi kanálmi. Slovenská archeológia 50, 2002, 245-322.

J. Ruttkayová: K problematike osídlenia severozápadného pomedzia avarského kaganátu v 7. -8. stor. In: K problematike osídlenia stredodunajskej oblasti vo včasnom stredoveku. Nitra 1991, 185-217.

J. Ruttkayová/M. Ruttkay: Včasnostredoveký sídliskový objekt v Čel’adiciach. In: G. Fusek (red.): Zborník na počest' Dariny Bialekovej. Nitra 2004, 319-328.

M. Soják: Výskumná správa z povrchového prieskumu lokality Smižany - Gnojník I, II za rok 1998. Výskumná správa 65/1998. Dokumentácia AÚ SAV. Nitra 1998. Nepublikované.

M. Soják: Prieskumy v okresoch Spišská Nová Ves a Levoča. AVANS 1998, 2000, 161-165.

M. Soják: Terénny prieskum na Spiši. AVANS 2000, 2001, 175-185.

M. Soják: Sídliskový objekt z Letanoviec. Študijné zvesti AÚ SAV 38, 2005, 137-154.

M. Soják: Osídlenie spišských jaskýn̆ od praveku po novovek. Nitra 2007.

M. Soják: Archeologické dejiny. In: M. Gonda/P. Špic/M. Kostelník/M. Soják/F. Žifčák (zost.): Spišské Tomášovce (1217-2017). Kežmarok 2017, 33-81.

M. Soják/P. Fecko: Smižany, okres Spišská Nová Ves. Výskumná správa 136/11. Dokumentácia AÚ SAV. Nitra 2011. Nepublikované.

D. Staššíková-Štukovská/P. Šalkovský/J. Béreš/E. Hajnalová/E. Huštaková/Z. Krempaská/F. Javorský: Včasnostredoveké Hradisko I. Spišské Tomášovce-Smižany. 1. etapa spracovania. Zborník SNM 100. Archeológia 16, 2006, 187-234. 
Šalkovský 1980

Šalkovský 1983

Šalkovský 1994

Šalkovský 1997

Šalkovský 1998

Šalkovský 2001

Šalkovský 2002

Šalkovský $2007 a$

Šalkovský 2007 b

Šalkovský 2009a

Šalkovský $2009 b$

Šalkovský 2011a

Šalkovský 2011 b

Točík 1963

Tomášová 1990

Turistický atlas

Vencko 1941

Vendtová 1964

VSS III 1978

Zábojník 2002

Zábojník 2004

Bielek 2004

Hraško a i. 2017

http://klimat.shmu.sk

LGis 2015
P. Šalkovský: K vývoju a štruktúre slovanského osídlenia v hornatých oblastiach Slovenska. In: IV. Medzinárodný kongres slovanskej archeológie Sofia 15.-22. septembra 1980. Zborník referátov ČSSR. Nitra 1980, 166-173.

P. Šalkovský: Štruktúra a formy osídlenia Slovenska v 6.-8. storočí ako sociálnoekonomické javy. Kandidátska dizertácia. Nitra 1983.

P. Šalkovský: Frühmittelalterlicher Burgwall bei Detva. Slovenská archeológia 42, 1994, 155-185.

P. Šalkovský: Slovanské hradisko pri Detve. Príspevok k rekonštrukcii dejín stredného Slovenska v 9.-11. storočí. In: R. Marsina/A. Ruttkay (ed.): Svätopluk 894-1994. Nitra 1997, 213-219.

P. Šalkovský: Dedinský dom a sídlo vo včasnom stredoveku. In: P. Šalkovský/ M. Ruttkay/J. Botík (ed.): L'udová architektúra a urbanizmus vidieckych sídiel na Slovensku z pohladu najnovších poznatkov archeológie a etnológie. Bratislava 1998, 9-36.

P. Šalkovský: Häuser in der frühmittelalterlichen slawischen Welt. Nitra 2001.

P. Šalkovský: Stavebná kultúra a urbanizmus osád. In: A. Ruttkay/M. Ruttkay/ P. Šalkovský (ed.): Slovensko vo včasnom stredoveku. Nitra 2002, 57-68.

P. Šalkovský: Problém obdížnikovitých a oválnych zemníc u Slovanov. Prilozi Instituta za archeologiju u Zagrebu 24, 2007, 301-307.

P. Šalkovský: Sídliskové objekty západného areálu včasnostredovekého hradiska v Spišských Tomášovciach. In: Zborník Filozofickej fakulty Univerzity Komenského, Musaica 25. Bratislava 2007, 113- 22.

P. Šalkovský: Najstaršie formy domov u Slovanov. In: Zborník Filozofickej fakulty Univerzity Komenského, Musaica 26. Bratislava 2009, 35-48.

P. Šalkovský: Frühmittelalterliche Grubenhäuser. Probleme der Terminologie, Typologie und Rekonstruktion. Archaeologia Adriatica 3, 2009, 273-292.

P. Šalkovský: Stredné Slovensko vo včasnom stredoveku. Nitra 2011.

P. Šalkovský: Včasnostredoveké kvadratické zemnice - problémy terminológie, typológie, interpretácie a rekonštrukcie. In: Zborník Filozofickej fakulty Univerzity Komenského, Musaica 27. Bratislava 2011, 159-182.

A. Točík: Pohrebisko a sídlisko z doby avarskej ríše v Prši. Slovenská archeológia 11, 1963, 121-198.

B. Tomášová: Záchranný výskum v Prešove. AVANS 1988, 1990, 161.

Turistický atlas Slovenska 1 : 50 000. 2 vydanie. Harmanec 2007.

J. Vencko: Z dejín okolia Spišského Hradu. Spišské Podhradie 1941.

V. Vendtová: Výskum v Slovenských Ďarmotách roku 1962. Archeologické rozhledy 16, 1964, 347-369.

Vlastivedný slovník obcí na Slovensku III. Bratislava 1978.

J. Zábojník: Slovensko a avarský kaganát. In: A. Ruttkay/M. Ruttkay/P. Šalkovský (ed.): Slovensko vo včasnom stredoveku. Nitra 2002, 29-39.

J. Zábojník: Slovensko a avarský kaganát. Bratislava 2004.

\section{Internetové zdroje}

P. Bielek: Pôdy Slovenska. Čiernica (ČA). Pôdohospodársky poradenský systém. http://old. agroporadenstvo.sk/rv/poda/ciernica.htm?start [cit. 29. 06. 2017].

J. Hraško/V. Linkeš/R. Šály/B. Šurina: Pôdna mapa Slovenska 1 : 400 000. http://www. podnemapy.sk/portal/prave_menu/podna_mapa/podna_mapa.aspx [cit. 19. 04. 2017]. Online interaktívna verzia Klimatického atlasu Slovenského hydrometeorologického ústavu http://klimat.shmu.sk/kas/ [cit. 29. 06. 2017].

Lesnícky geografický informačný systém. Národné lesnícke centrum Zvolen 2015 http://gis.nlcsk.org/lgis/ [cit. 11. 05. 2017]. 


\title{
A contribution to the settlement of Smižany in the Early Middle Ages
}

\author{
Peter Fecko - Marián Soják
}

Summary

The goal of the study is to present the results of the archaeological trench excavations carried out in 2011 during the construction of the TESCO Shopping Centre in the village of Smižany (Fig. 1; 2: 2). During the investigation, a settlement feature was detected in Trench III/11 (Fig. 3-5), which - based on the analysis of pottery- is roughly dated to the $8^{\text {th }}-9^{\text {th }}$ century.

The feature is a regularly oval groundplan of the sunken part of the feature with NW - SE orientation. Due to excavations for gas pipeline in the past, not whole grundplan has been preserved (Fig. 6). Remains of an unknow dry masonry(?) possibly representing a postmedieval pavement were uncovered behind the western edge of the feature (Fig. $4: 2 ; 5 ; 6)$.

Assuming that the groundplan was regularly oval, the lenght of the feature could have reached $4.5-5 \mathrm{~m}$ and its width could have been 2.5-3 m, which means an area of approx. $12 \mathrm{~m}^{2}$. After the feature had been studied, its depth reached $95 \mathrm{~cm}$ below the current terrain. It was sunk 20-30 cm deep in the sterile subsoil.

Based on the typology by P. Šalkovský $(2001,18 ; 2007 a, 302 ; 2011 b, 174)$, we classify the feature within his type 3, which is associated mainly with the mountainous areas of Central and Eastern Slovakia, Moravia and Bohemia (Šalkovský $2007 a, 301 ; 2011 a, 19)$. Following from the detailed analyses by the above mentioned author (Šalkovský 1998, 14; 2001, $18,42,55,56 ; 2007 a ; 2009 b, 278,279)$, we interprete Feature 1 as a pithouse with a light log or frame construction in the overground part. We consider a dual-pitched gable roof which either touched the ground or was set in wooden walls built around the central pit (Šalkovský 2007a, obr. 2: 2; 2009a, 43; 2011a, 21). We assume a residential character of the feature. It is indicated mostly by the character of the discovered artifacts. Absence of a hearth can be associated with the fact that not the whole groundplan of the feature was detected and the hearth could have been situated in the previously destroyed part. A similar case of an absent hearth in a residential feature is known from the Great Moravian settlement in Branč, where no type of a heating device was recorded in Feature 157 (Hanuliak/Vladár 2008, 88 n., fig. 4: 2). The authors of the article state that such features might have been used for occassional stays or longer accommodation in times of emergency. We incline to the opinion that the hearth did not have to be necessarily built in the same time as the structure itself; it might have been built later (Hanuliak/Vladár 2008, 90).

216 fragments of pot-shaped vessels with simply S-profiled lower mouths come from Feature 1 . The pots were made by coiling on a slowly spinning manual potter's wheel. There are mainly thick-walled and well-fired sherds with admixture of sand and mica, with rough structure of their outer surface. At least 12 types of vessels can be identified from the fragments (Fig. 7-10:1-3). It was possible to completely reconstruct one vessel (Fig. 7: 1; 12: 2). Among decorative motifs, comb decoration in from of multiple wavy lines prevails (Fig. 7-10). As far as other motifs are concerned, there are multiple engraved girth lines with multiple wavy lines (Fig $8: 1,3 ; 9: 1 ; 10 ; 18-20$ ). A combination of multiple wavy lines and a comb incision was found only on two exemplars (Fig. 8: 2; 10: 1). Less frequently, combinations of a simple wavy line and multiple wavy lines (Fig. 7: 2; 10:3) or a simple wavy line and a comb incision occured (Fig. 10: 11). A sprig motif can be assumed only in one case, however, not the whole part of decoration has been preserved (Fig. 9: 3). In two cases, the inner side of the mouth was decorated with a wavy line (Fig. 8: 3; 9: 3). Besides pot-shaped vessels, a ceramic fragment of a pan was identified in one case (Fig. 10: 12).

Besides sherds, four sandstone whetstones were discovered in the feature (Fig. 13: 1). Textile production is documented by the find of a biconical clay spindle whorl (Fig. 13: 3) and two smoothed fragments of bone awls (Fig. 13: 4, 5). Processing by cutting is visible on one of the animal bones (Fig. 13: 2).

The above mentioned pithouse from the site of TESCO certainly belongs to the system of Slavonic settlements which probably made up the economic background for the Čingov hillforts in Spišské Tomášovce/Smižany (10, 11). From the cadastral area of Smižany, we have recorded several sties dated to the Early Middle Ages (Fig. 1): the sites of Ulica kpt. J. Nálepku (2), Zlaté role (3), Pri kňazovej studni (4), Štrkovisko IV (5), Smižianska Maša (6), Baniská, Gnojník (7), Smižianska roveň (8), Sedlo pod hradiskom (9), Čingov (12) - also called Pri starej horárni and the Tri skalky cave (13). The dominant hill called Matka Božia (Mother of God) (14) mentioned in literature as a Slavonic cultic place (Javorský 1978 , 111) cannot be confirmed nor denied due to absent evidence.

Based of the physical re-evaluation of the available ceramic material, we can see that most finds come from surface surveys which can be roughly dated to the $8^{\text {th }}-10^{\text {th }}$ centuries. During revision, however, some fragments roughly dated to the early phase of the Early Middle Ages were identified among the sherds (more details on page 14).

The only suitable means for dating of Feature 1 at the site of TESCO is the ceramic assemblage found in it. The assemblage as a whole with certain characteristic features was compared with the material of individual older or younger horizons of the early medieval closed finds from Spiš. As for the older horizon, we can mention the site in Spišský Štvrtok-Šibeničná hora from the end of the $6^{\text {th }}$ /beginning of the $7^{\text {th }}$ century or the site of Iliašovce-Za hostincom. 
In 2016-2017, previously unpublished settlement features dated to the $7^{\text {th }}$ century were uncovered in Spišská Nová VesPod Modrým vrchom site. They contained hand-made pottery. At the site of Spišský Štvrtok-Široké III, parts of sunken dwellings damaged during humus removal were studied during the rescue excavations in 1988. In the undamaged parts of two features, F. Javorský reportedly detected trimmed floors and hearths. He dated the pottery found in them to the $8^{\text {th }}-10^{\text {th }}$ centuries (Javorsky $1990 b, 87$ ). After the physical re-evaluation of the sherds including hand-made pottery together with coiled exemplars, it was discovered that the found pottery assemblage can be dated earlier, to the $7^{\text {th }}-8^{\text {th }}$ centuries. As for the pottery from the younger horizon $\left(9^{\text {th }}-10^{\text {th }}\right.$ centuries), we followed e. g. from a comparison of the pottery assemblage from the feature - pithouse 17/80 - in Spišská Nová Ves (ČaplovičlJavorský 1990, 75, 87; Javorský 1981, 111, obr. 52: 3-6). In the region of Spiš, this younger pottery is technologically more advanced. The vessels are better coiled with more distinct profiles of rims. Their surface is finer. In decoration, occurrence of horizontal fluting is applied, occasionally changing into low wavy lines which sometimes overlap. The decoration - waves or horizontal lines - is sparser and created by a wider single-tip tool.

With its character, the pottery assemblage from Feature 1 at the site of TESCO bears features of pottery relatively dated to the $8^{\text {th }}-9^{\text {th }}$ century in the Slovak expert literature (for another list of settlements with analogies see Fusek 2008, 28, 33, 34; Hanuliak 2016, 121, 122). The lower limit is set by the absence of hand-made pottery which moves the chronological identification approx. to the second half of the $8^{\text {th }}$ century (MarkoválElschek 2002, 219; Fusek 2008, 30, 33; $2013,146)$. Gradual disappearing of older traditions was recognized also in ornamentation represented by the ornament in form of short horizontal or oblique comb incisions or cuts incorporated below the neck or on shoulders (Fig. 8: 2; 9: 3; 10: 1, 11, 14). The popularity of such decoration in Western Slovakia is - according to G. Fusek $(2008,32)$ - typical of the $8^{\text {th }}-9^{\text {th }}$ centuries.

Vessels with mouths decorated by a wavy line on the inner side (Fig. 8: 3; 9: 3) are relevantly represented. It is an archaic decorative element which occurs on pottery around the mid $7^{\text {th }}$ century; however, they were most frequent in the following $8^{\text {th }}$ century with gradual disappearance in the $9^{\text {th }}$ century $($ Fusek $1994 a, 63,64 ; 2008,32,33 ;$ Galuška 1987, 78, 79; Rejholcová 1977, 654; Šalkovský 2011a, 45, 48).

As for the chronological classification of the pithouse from Smižany within the $8^{\text {th }}-9^{\text {th }}$ century, we can follow besides pottery - also from the types of dwellings. It is known from literature (Šalkovský 1983, 120; 2011a, 21) that the dominance of this type of dwellings occured in the $7^{\text {th }}-8^{\text {th }}$ centuries. In Slovakia, this type of features (type 3 ) survives in later centuries, mostly in northeastern and Central Slovakia (Šalkovský 1983, 14).

The direct re-evaluation of the pottery deposited in the depository of the IA SAS in Spišská Nová Ves was most beneficial for our knowledge of the early medieval settlement in the cadastral area of Smižany. Identification of pottery fragments shifting the settlement's dating probably as early as the second half of the $6^{\text {th }}$ century is important. The comparative analysis of dating (Fig. 14) on the basis of data from literature and then according to the direct study of pottery has brought new information on the settlement of the cadastral area in the Early Middle Ages. Based on the cartographic processing, it can be seen that the settlement is concentrated mainly in the climatically more favourable area of the Hornádska kotlina basin near the stream of Brusník, mainly on its left banks and on the left-bank terrace of the Hornád river in the altitude of 460-550 m. Most frequently, places with prevailing most fertile type of soil - black soil - are settled.

Our ambition in the submitted article is not dealing with the relative chronology of the Early Middle Ages in Spiš. Nevertheless, we wanted to point to the importance of the closed finds in which pottery is the only means for chonological classification. We also wanted to point to the importance of physical work (if possible) with material sources - pottery in our case - together with working with literature. The knowledge of the typological content of pottery changes in time, thus, it is important to re-evaluate it repeatedly.

Fig. 1. Smižany. The cadastral area of the village with indicated sites dated to the Early Middle Ages. Numbers of the sites are identical with the numbers of the sites in the text. 1 - OD TESCO; 2 - Ulica kpt. J. Nálepku; 3 - Zlaté role; 4 - Pri kňazovej studni; 5a - Štrkovisko IV; 5b - Štrkovisko II; 6 - Smižianska Maša; 7 - Gnojník; 8 - Smižianska roveň; 9 - Sedlo pod hradiskom; 10 - Hradisko I; 11 - Hradisko II; 12 - Čingov (Pri starej horárni); 13 - the cave of Tri skalky; 14 - Matka Božia; 15 - Turník. Source QGIS, edited by P. Fecko.

Fig. 2. Cadastral area of the village of Smižany. 1 - soil map. Legend: H1 - typical saturated to acid cambisols; H6 - cambisols, saturated pseudogleysols; H7 - dystric cambisols and typical acid cambisols; H10 - dystric cambisols; R1 rendzinas and rendzina cambisols; R2 - typical lithium and rubified rendzinas; R3 - leached rendzinas and rendzina cambisol; P2 - cambisol podzols; L3 - typical carbonate black soils (after Hraško a i. 2017, edited by P. Fecko). 2 - Hypsometric map. Legend: a - 460-550 m above sea level; b-550-600 m a. s. 1.; c-600-650 m a. s. 1.; d -650-700 m a. s. 1.; e - 700-750 m a. s. 1.; f - 750-800 m a. s. 1.; g-800-850 m a. s. 1.; h-850-900 m a. s. 1.; i-900-950 m a. s. 1.; j-950+ m a. s. 1. (after P. Fecko). The numbers of the sites correspond with the numbers of the sites in the text and with Figure 1.

Fig. 3. Smižany, OD TESCO site. 1 - location of archaeological trenches I-III from 2011 on the orthophotomap (sources used background of Orthophoto map by Ortofoto@Geodis, processed by P. Fecko in ArcGIS software). 2 - location of archaeological trenches I-III in 3D representation. Source Google Earth.

Fig. 4. Smižany, OD TESCO site, Trench III/11, Feature 1. 1 - detected southeastern part of the feature $70 \mathrm{~cm}$ below the current terrain; 2 - expansion of the feature westwards.

Fig. 5. Smižany, OD TESCO site, Trench III/11, Feature 1. 1; 2 - view of the studied feature.

Fig. 6. Smižany, OD TESCO site, Trench III/11, Feature 1. 1 Groundplan and profiles after removal of soil down to the sterile subsoil. Legend: a - upper layer of dark black soil mixed with smaller fragements of gravel and grass roots; 
b - dark black cinder mixed with postmedieval waste and gravel; c - grey to grey-brown soil mixed with postmedieval bricks and gravel (made-up ground); $\mathrm{d}$ - cultivated soil of brown colour, compact, with concentration of archaeological finds from the Post-medieval and early medieval periods; e - Feature 1. Dark black soil, compact, with concentration of early medieval archaeological finds; $\mathrm{f}$ - trial trench excavated by construction workers to detect the location of gas pipeline; $\mathrm{g}$ - yellow foil above the gas pipeline; $\mathrm{h}$ - waterworks concrete ring; $\mathrm{i}$ - furrow of the gas pipeline; $j$ - edge of the furrow for the gas pipeline, sterile soil mixed with topsoil; $k$ - fragments of postmedieval bricks; 1 - sandstone; $\mathrm{m}$ - burned sandstone; $\mathrm{n}$ - assumed course of the features. Drawing by P. Fecko.

Fig. 7. Smižany, OD TESCO site, Trench III/11, Feature 1. Selected pottery finds. Drawing by 1 - E. Bakytová; 2 - P. Fecko. Fig. 8. Smižany, OD TESCO site, Trench III/11, Feature 1. Selected pottery finds. Scale: a - 1, 2; b - 3. Drawing by P. Fecko. Fig. 9. Smižany, OD TESCO site, Trench III/11, Feature 1. Selected pottery finds. Drawing by P. Fecko.

Fig. 10. Smižany, OD TESCO site, Trench III/11, Feature 1. Selected pottery finds. Scale: a - 12; b - 1-11, 13-23. Drawing by P. Fecko.

Fig. 11. Smižany, OD TESCO site, Trench III/11, Feature 1. Selected pottery finds. Drawing by P. Fecko.

Fig. 12. Smižany, OD TESCO site, Trench III/11, Feature 1. Selected pottery finds. Scale: $a-1 ; b-2$. Drawing and photo by P. Fecko.

Fig. 13. Smižany, OD TESCO site, Trench III/11, Feature 1. Miniature finds. 1 - lithic whetstone; 2 - bone processed by cutting; 3 - clay spindle whorl; 4, 5 - bone awls. Photo by P. Fecko.

Fig. 14. Smižany, analysis of dating of the Early Middle Ages $\left(6^{\text {th }}-10^{\text {th }}\right.$ centuries). 1 - comparison of dating of sites in the cadastral area of the village according to literature and on the basis of physical re-evaluation of pottery; 2 - dynamics of settlement in the cadastral area elaborated on the basis of the dating presented in literature; 3 - dynamics of settlement in the cadastral area elaborated on the basis of physical re-evaluation of pottery. Legend: a - number of sites from the given century identified after the pottery re-evaluation; $b$ - number of sites from the given century identified according to literature; $\mathrm{c}$ - moving average of the chronological curve determined on the basis of the pottery re-evaluation; $\mathrm{d}$-moving average of the chronological curve determined by the literature.

Mgr. Peter Fecko

Archeologický ústav SAV

Oddelenie záchranných výskumov - Spiš

Mlynská 6

SK - 05201 Spišská Nová Ves

feckop@gmail.com

PhDr. Marián Soják, PhD.

Archeologický ústav SAV

Oddelenie záchranných výskumov - Spiš

Mlynská 6

SK - 05201 Spišská Nová Ves

sojak@ta3.sk 
